\title{
LA MÚSICA EN LA REAL COLEGIATA DEL SANTO SEPULCRO DE CALATAYUD *
}

Resumen: Este artículo pretende aproximar al investigador un material (fuentes musicales impresas y manuscritas, listados de músicos, instrumentos, etc.) surgido a partir de la reciente impresas y manuscritas, listados de musicos, instrumentos, etc.) surgido a partir de la reciente catalogación del archivo de música de la Colegiata del Santo Sepulcro de Calatayud. Se ofrece información sobre el paradero de la documentación dispersa con motivo de las desamortizaciones del
siglo XIX; se aporta un listado del contenido de los códices musicales conservados; y se resume el panorama de su fondo de música "a papeles" (con relación de autores reflejados en el archivo y un breve repaso por el repertorio). Por último, se extracta la historia musical de la colegiata, dando nombres de músicos y fechas de su actividad, desde fines del siglo XVI hasta la paulatina desaparición de la capilla de música, ya bien entrado el siglo XX".

Music in the Royal Collegial Church of the Holy Sepulchre of Calatayud

Abstract: This article intends to provide scholars with a material (printed and manuscript musical sources, lists of musicians, instruments...) derived from the recent work of catalogue in the music archive of the Collegial Church of the Holy Sepulchre of Calatayud. Information is given on the location of the documents dispersed during the expropriations of the XIXth century, including a list of the content of the extant music codex, as well as a summary of the Collegial funds of music "a papeles" (with a list of the authors included in the archive and a brief comment on the repertoire). Finally, there is a description of the musical history of the Church since the XVIth century, until the gradual disappearance of the music chapel in the XXth century.

"Nuestro agradecimiento y recuerdo para D. Jacinto Alcoitía, último Prior de esta Colegiata, recientemente desaparecido, a cuya memoria dedicamos las líneas de este trabajo. Sin su ayuda y múltiples fallade guel Gonzalez, sá cho fácil y agradable nuestro paso por la iglesia. 
El presente artículo no pretende hacer un estudio especialmente reflexivo ni ofrecer una valoración de unos determinados fondos musicales. Trata, más bien, de aproximar a otros investigadores y estudiosos unos materiales de primera mano, desconocidos hasta la fecha para la investigación, que pueden ser de utilidad de cara a la delineación - a partir de ejemplos locales como el presente- de una historia de la música aragonesa, y por extensión, española, asentada en el conocimiento de las fuentes que se nos han conservado.

En este sentido, este trabajo pretende servir como "adelanto" informativo de las fuentes localizadas, pues su concepción arranca del catálogo informatizado del archivo musical de la Colegiata del Santo Sepulcro de Calatayud que acabamos de finalizar. Los datos que aquí se aportan, por tanto, complementan y completan dicho catálogo, para cuya confección se ha procurado ofrecer el mayor grado de rigor en el tratamiento histórico y documental posible. Lo que, a la postre, intenta redundar en "fiabilidad".

De la misma manera, en determinadas ocasiones nos ha parecido oportuno no escatimar datos o informaciones de carácter histórico o documental, aunque no propiamente de interés musical, con vistas a aportar el máximo de "pistas" posibles al estudioso interesado en profundizar en alguna faceta determinada - aquí seguramente, únicamente esbozada - relacionada con estos fondos. Por esta razón, ha de tomarse el amplio aparato de notas al pie como lo que es: un apartado de ayuda o complemento, que el lector podrá pasar por alto según su interés particular, con vistas a no perder el hilo natural de la narración.

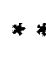

Los escasos datos conocidos hasta hoy sobre la riquísima historia musical de la ciudad de Calatayud, se refieren en su práctica totalidad a la considerada como su iglesia principal, la Colegiata de Santa María. En cambio, la bibliografía disponible apenas dice nada sobre la música de otros templos de la ciudad asimismo relevantes en tiempos pasados, como, por ejemplo, la Colegiata del Santo Sepulcro, $\mathrm{u}$ otras destacadas iglesias parroquiales (San Pedro de los Francos, la que fuera colegiata de Nuestra Señora de la Peña, San Juan el Real, San Andrés, etc.). La mayoría de dichos templos gozaron alguna vez de capilla de música propia.

Como es bien conocido desde el punto de vista histórico, la actual fábrica de la bilbilitana Iglesia Colegiata del Santo Sepulcro, casa matriz de la Orden de los Caballeros del Santo Sepulcro de Jerusalén en España, data de 1613, a partir de cuya fecha el capítulo de dicha "Iglesia Jerosolymitana» ${ }^{1}$ iba a vivir una etapa de particular esplendor. El título del que goza ésta, al menos desde finales del siglo XVII, la denomina como «Iglesia Colegial, Insigne Casa Real y Regular, Mayor, y Preeminente del Santo Sepulcro Hierosolimitano de Calatayud $»^{2}$.

La historia de la iglesia, y de su relación con la orden de caballería pontificia bajo la misma advocación, es larga ${ }^{3}$.

IEn la actualidad, la Orden reúne a unos cuatro mil miembros en todo el mundo, entre caballeros, comendadores, grandes oficiales y grandes cruces, que se agrupan en asociaciones nacionales. Entre sus actividades -inspiradas por el espíritu cristiano y la defensa de la religión-, realizan obras de caridad, especialmente con necesitados y enfermos de Tierra Santa, así como otras obras culturales y sociales (mantenimiento de los Santos Lugares) como presencia activa de la Iglesia católica en Tierra Santa. Para nuestro caso, conviene señalar que en Aragón existieron también Comunidades de Religiosas de la Orden en Huesca, Zaragoza y Calatayud, aunque actualmente sólo quedan en Zaragoza, en cuyo monasterio, por cierto, se conserva un órgano positivo del siglo XVI, como testimonio de la importancia que históricamente se ha otorgado a la música en los templos al cuidado de la orden $\rightarrow$ todavia se celebran ahí los oficios con canto gregoriano-. Los instrumentos ahí conservados, así como la abundante y privilegiada documentación musical, son testigos de excepción de un sobresaliente esplendor pasado.

${ }^{2}$ Según se lee en el volumen titulado Caj.n Cathedralidad $/ n^{\circ} .18^{\circ}$, de la biblioteca de la bilbilitana Colegiata de Santa María. Este libro reúne diversos cuademillos impresos, algunos de ellos datados en 1677 . Se trata ahí del pleito acerca de la catedralidad que mantuvo por entonces la colegial de Sanen 167 . Se trata ahi del pleito acerca de la catedralidad que mantuvo por entonces la colegial de Santa María con la seo de Tarazona; otros cuadernillos en cambio, de mayor interés para nosotros, relatan mir cuál de las dos gozaba de preeminencia sobre la otra. ${ }^{3}$ La Orden fue fundata en 1099 por

La Orden fue fundada en 109 por el cruzado Godofredo IV de Boulogne - más conocido como Godofredo de Buillón (+1100)-, defensor y "protector» del Santo Sepulcro de Jerusalén, quien, tras la entrada de los cruzados en la ciudad santa, instauró una congregación de religiosos para que protegieran la tumba de Cristo con ayuda de algunos caballeros. Muy pronto, el prestigio de la nueva congregación se acrecentó de tal modo, que incluso algunos de sus Priores llegaron a ser Patriarcas de Jerusalén. El papa Calixto II ( +1124$)$ regularizó a los canónigos, que a partir de entonces, aparte de salir en ocasiones al campo de batalla, vivieron en comunidad según la regla de San Agustín. De unos años más tarde data el origen de la Orden en la peninsula, establecida primeramente en Aragón y Cataluña, a raíz de la muerte sin descendencia legítima del rey aragonés Alfonso I el Batallador (†Fraga - Huesca-, 1134), quien había dejado mediante testamento su reino a la Orden del Santo Sepulcro, juntamente con la del Hospital y la del Temple. Más adelante, tras diversos conflictos, y pactar con Ramón Berenguer IV, la Orden, desde Jerusalén, enviaría sus derechos a la Corona, renunciando a ella y recibiendo a cambio, entre otras compensaciones, un amplio territorio en Calatayud, donde se fundó la casa madre de la orden. Para hacerse cargo de la situación acudió a Calatayud el canónigo Giraldo, y en 1144 los caballeros recibían ya la primera concesión, que fue la donación del solar donde edificaron la actual iglesia colegiata. Posteriormente, los caballeros recibieron diversas recompensas por parte de los monarcas aragoneses, como fueros y otras donaciones, merced a sus acciones bélicas durante la $\mathrm{Re}-$ conquista. Ya para el siglo XV, Inocencio VIII (†Roma 1492), enfrentado con el también rey de Nápoles, Fernando de Aragón, suprimió la Orden, incorporándola a la de San Juan de Jerusalén -1489aunque en España conservó su autonomía. Fue renovada luego por Alejandro VI en 1496. En el siglo XVI, se suprimiría la Orden de nuevo, aunque el Cabildo de Calatayud recibió entonces la aprobación del papa León $X$ (con el paso de los años, la comunidad bilbilitana había quedado bajo dependencia directa de la Santa Sede, y mantenía su independencia de la jerarquía eclesiástica hispana). 
La dedicación de la iglesia determinó, ya desde su fundación, con vistas a solemnizar la liturgia, algunos de los temas a tratar con mayor profusión desde el punto de vista musical. De este modo, tanto el canto del Passio, como la composición de Lamentaciones para la Semana Santa, u otras composiciones propias del Oficio de Difuntos (Misas de Requiem, secuencias «Dies iræ», Lecciones de difuntos como el "Parce mihi, Domine», o incluso Responsos para los muertos, o salmos como el «Miserere»), cobraron un destacado papel entre las obras que debieron concebir sus músicos, ya fueran éstos maestros de capilla $u$ organistas ${ }^{4}$.

Afortunadamente, la presencia musical en esta iglesia ha quedado muy bien documentada, por cuanto su archivo se ha revelado como uno de los más nutridos e interesantes de Aragón en cuanto a música se refiere ${ }^{5}$. Recientemente, hemos procedido a su catalogación según la normativa del RISM (Répertoire International des Sources Musicales) ${ }^{6}$, incorporando además algunos

Con el tiempo, incluso llegó a tal grado el prestigio de que gozaban los miembros del capítulo bilbilitano -muchos de ellos procedentes de la nobleza-, que cuando pasaban los reyes por Calatayud se hospedaban con la Comunidad. A nivel internacional, se produjo un lento aunque paulatino proceso de "nacionalización" de estas órdenes: en 1734 era ya el rey de España el que nombraba a los canóngos de Calatayud; posteriormente, continuas guerras y desamortizaciones eclesiásticas, a pesar del notable empuje e influencia en el ámbito sociopolítico y económico del cabildo bilbilitano, trajeron consigo la supresión, en 1857, de la Comunidad de Calatayud, pasando su último Prior a ser nombrado Canónigo de Málaga. Desde entonces, como sucediera a tantísimos templos hispanos, la prominente iglesia perdió su anterior categoría, quedando reducida a "Parroquia", hasta que en 1901 fue restituida en la condición que le correspondia por abolengo y reputación, siendo de nuevo declarada por nombramiento real, "COLEGIATA". Sin embargo, desde entonces, algunos de sus anteriores privilegios fueron abolidos: sus Priores y Canónigos iban a ser ahora nombrados por el Obispo de Tarazona, y dejarian de ser Regulares, para pasar a ser Diocesanos, quedando así la Orden, en la práctica -junto a las demás órdenes supervivientes-, relegada a mera institución honorifica.

De forma semejante, en el interior de la iglesia, todos los retablos (ocho, - los laterales, con relieve policromados--, realizados en talleres bilbilitanos) están dedicados al tema de la Pasión de Cristo, en un particular y extraordinario caso monotemático, único dedicado en exclusiva a este asunto en España.

${ }^{5}$ Desde hace once años, coordinamos un equipo de investigación y estudio de los archivos ecle siástico-musicales de Calatayud (agradecemos la participación sucesiva de Montserrat Sánchez, Jordi Ardèvol, $\mathrm{M}^{\mathbf{a}}$ Antonia Guerrero, e Isabel Gallardo).

- En este sentido, se ha finalizado la catalogación informatizada de los archivos de música de la Colegiata de Santa María, y también de la Colegiata del Santo Sepulcro. Los primeros datos aportados por el RISM sobre la música conservada en la colegial bilbilitana de Santa María, aparecieron publicados en 1972 en su Serie C -Directorio de Archivos y Bibliotecas-. Véase: BENTON, Rita: Directory of Music Research Libraries. Part IIl: Spain, France, Italy, Portugal. RISM Serie C/III. Iowa City, 1972 cfr. p.15). No se recogía ahí en cambio referencia alguna sobre la música en la colegial del Santo Sepulcro. Desde entonces, hemos incorporado datos relativos a la música en ambas colegiatas en "Zentralredaktion" del RISM en Francfort, sugiriendo, desde el grupo de trabajo RISM-España, siglas normalizadas para sus citas bibliográficas a nivel internacional, las cuales han sido ya adoptadas en los más de treinta países miembros: $E: C A L=$ Colegiata de Santa Maria: $E$ : $C A L S=$ Colegiata del Santo Sepulcro. Cfr: RISM Bibliothekssigel. Gesamtverzeichnis. (Bearbeitet von der RISM-Zentralredaktion und den RISM-Ländergruppen). Munich, G. Henle, 1998; véanse especialmente pp.47-51. datos fruto de nuestro trabajo en los nuevos soportes que nos proporciona la tecnología ${ }^{7}$. Actualmente, se conservan en el archivo de música del Santo Sepulcro bilbilitano, además de varios libros de polifonía, pasionarios, libros corales litúrgicos, etc., unas mil quinientas composiciones musicales, tanto impresas como manuscritas, "a papeles" (es decir, en papeles sueltos), de los siglos XVIII al XX, y en su mayor parte, inéditas. Un importante patrimonio histórico-musical, y por tanto, cultural, propio, que tenemos la responsabilidad y el deber de dar a conocer ${ }^{8}$.

De dicho fondo "a papeles", formado en su mayor parte por el repertorio habitual en nuestros templos (música litúrgica del tipo misas, salmos, motetes, lamentaciones, antífonas, etc., y música paralitúrgica en lengua vernácula, del tipo villancicos, tonadillas, gozos, letrillas, jaculatorias, etc.) ${ }^{9}$, cabe destacar ${ }^{7}$ Hemos incorporado a la base de datos internacional del RISM (programa PIKaDo $=$ Pflege und
Information Kategorisierte Dokumente) y a la edición de la Serie A/II del RISM en CD-ROM (K.G. Information Kategorisierte Dokumente) y a la edición de la Serie A/II del RISM en CD-ROM (K.G. Saur Verlag, Munich), las fichas catalográficas de todas las composiciones musicales recogidas en los cantorales polifónicos de la colegial de Santa Maria. En la actualidad, se encuentran a la espera de su procesamiento informático más de 1.000 fichas procedentes del archivo musical de Santa María, y otras tantas del archivo del Santo Sepulcro. En un plazo seguramente breve, estos materiales podrán ser servidos a cualquier usuario, a nivel internacional, libres de costes, a traves del grupo de trabajo RISM-US, ubicado en la Universidad de Harvard, por medio de su dirección abierta para la consulta en Internet: http://rism.harvard.edu/rism/db.html. Con ello, las fichas catalográficas relativas a la documentación musical conservada en Calatayud podrán ser accesibles "on line" desde cualquier lugar del mundo. [Sobre el RISM y sus actividades, vid.: CONZÁLEZ VALLE, José Vicente; EZQUERRO, Antonio; IGLESIAS, Nieves; GOSÁLVEZ, C. José; y CRESPf, Joana, eds.: Normas Internacionales para la catalogación de fuentes musicales históricas. RISM Serie A/I. Manuscritos musicales 1600-1850. Madrid, Arco Libros, 1996. GONZÁLEZ VALLE, José Vicente; y EZQUERRO, Antonio: RISM Serie AAI Manuscritos musicales desde 1600. catálogo temático. 5. und 6. kumulierte Ausgabe (3. und 4.CD-ROM). Munich-New Providence-Londres-París, K. G. Saur Verlag (Electronic Publishing), 1998 -traducción española del CD-ROM, manual y folletos informativos-. EZQUERRO, Antonio: “Cataloguing Musical Sources in Spain: A RISM Perspective". En: Fontes Artis Musica, XLV/1, Nueva York-Madison, Wisconsin, January-March, 1998, pp.81-89. RISM-ESPANAA: Notas sobre manuscritos de müsica histórica española. (Materiales depositados en la Redacción Central del RISM-España, CSIC, Barcelona). Barcelona, edición prototipo en CD-ROM, ed. PROCO, 1998 -recoge 33.860 antiguas tarjetas catalográficas, digitalizadas, de composiciones musicales conservadas en archivos y bibliotecas de toda España, entre otras, algunas procedentes de las dos colegiatas de Calatayud--].

${ }^{8}$ Véase: EZQUERRO, Antonio: “El patrimonio musical de la Iglesia española: el caso de las catedrales y su patrimonio documental". En: Master de Restauración y Rehabilitación del Patrimonio. Cuadernos Temáticos del Patrimonio $N^{*}$ 2, (Jornadas Técnicas de Conservadores de las Catedrales de España). Vol. II. Madrid, Dirección General del Patrimonio Cultural (Junta de Castilla y León), 1998.

${ }^{9}$ El repertorio musical conservado, responde al propio de cualquier otra iglesia de relevancia española (catedral o colegiata). Se conservan: •Música litúrgica: Misas, y partes sueltas del «Ordinarium Miss Misas de Requiem, y partes del Oficio de Difuntos (lecciones, invitatorios, responsos...); Te Deum; Secuencias; partes del «Proprium Missæ» (introitos, tractos, ofertorios, alelluias, graduales); Juegos enteros de Visperas, y de Completas, y sus salmos sueltos; Responsorios; Salmos; Lamentaciones; Motetes; Himde Visperas, y de Completas, y sus salmos sueltos; Responsorios; Salmos; Lamentaciones; Motetes; Him-
nos; Cantica (Magnificat, Nunc dimittis, Benedictus); Salves; otras antifonas; Letanías... $\bullet$ Música paralitürnos; Cantica (Magnificat, Nune dimittis, Benedictus), Salves, otras antifonas, Letar. Siete Dolores; Misterios dolorosos; Rosarios; Santo Dios; Dúos; Tercetos; Coros; Gozos; Letrillas... 
además, por lo infrecuente de su presencia en los archivos eclesiásticos hispanos - al menos, en relación a la importancia porcentual que aquí adquiere esta música en comparación con el total de los fondos-, una interesante colección de música dramática (óperas, zarzuelas, oratorios, cantatas, recitados y arias, cavatinas... $)^{10}$, así como un relativamente abultado grupo de piezas exclusivamente de música instrumental (aparte de la frecuente literatura organística y para otro tipo de instrumentos de tecla —clavicordio, cémbalo, piano, harmonium...-, numerosos dúos, tercetos, cuartetos y quintetos de cámara, piezas para fagot, oberturas y sinfonías, bailes - ya orquestados, ya para instrumento solista- del tipo rigodones, valses, minués o mazurkas, entre otro tipo de obras muy variadas) ${ }^{11}$, de bastante interés, dado que, fuera de archivos y bibliotecas civiles o privadas, no abundan los grandes conjuntos de este tipo de literatura en nuestro país, lo que, aquí, acaso fuera favorecido por el componente de extracción "civil" —aunque religioso-, de fuerte influencia social y poderío económico, que pudo promocionar este tipo de música en un templo católico gracias a la presencia de la orden de caballeros del Santo Sepulcro.

Por otro lado, el hecho de que el grueso del archivo lo conforme música desde la segunda mitad del siglo XVIII hasta el primer tercio del siglo XX, viene a decirnos que existen períodos de tiempo de los que no se nos han conservado partituras u otro tipo de materiales músico-prácticos (libretes, cantorales, borradores, guiones orquestales...). A pesar de que nos consta por referencias documentales que la antigua iglesia del Santo Sepulcro tuvo capilla musical activa, al menos desde la segunda mitad del siglo XVI, desconocemos hasta el momento el paradero que pudo seguir toda la música que sin duda se habría compuesto desde dicha fecha, hasta la segunda mitad del siglo XVIII, término "a quo" para la música conservada.

En la práctica, la documentación de interés musical procedente de esta iglesia se conserva repartida, como veremos a continuación, entre el nutrido archivo ubicado en el propio templo, el Archivo Histórico Diocesano de Tarazona, y el Archivo Histórico Nacional de Madrid.

En este sentido, conviene relatar cuál fue el discurrir histórico de los archivos bilbilitanos, puesto que éste nos ayudará a comprender mejor las im-

${ }^{10} \mathrm{Cfr}$.: EZQUERRO, Antonio: "Ideas para desarrollar: cuestiones en torno a la formación de los archivos musicales eclesiásticos en España. El archivo como proceso de desarrollo". En: AEDOM. Boletín de la Asociación Española de Documentaciön Musical, Año IV, $\mathrm{N}^{\circ} 1$, Madrid, Enero-Junio, 1997, pp. 5-70

${ }^{11}$ Marchas patrióticas, ejercicios de oposiciones (al magisterio de capilla o la organistia), métodos (de solfeo, de canto, instrumentales...), etc. portantes carencias y lagunas del archivo musical de la propia iglesia del Santo Sepulcro ${ }^{12}$ :

"La mayor parte de la documentación —de todo tipo- procedente del archivo de la Colegiata de Santa María de Calatayud fue incautada en virtud de las leyes desamortizadoras del S. XIX. Debido a estas medidas, la Colegiata de Santa María había sido suprimida como tal en 1851.

El 26.04.1868, Andrés Doncel, encargado de la incautación de los Archivos de la provincia de Zaragoza, escribía desde Calatayud diciendo que había terminado el inventario del Archivo de la Colegiata de Santa María y que sólo le quedaba ultimar el de la iglesia del Santo Sepulcro para proceder a su traslado a Zaragoza. Para subvenir a los gastos, pedía que se le entregasen a través del habilitado del Cuerpo de Archiveros de 200 a 300 escudos.

Entretanto, el vocal de la recién creada Junta de Archiveros, Bibliotecas y Museos, el aragonés Vicente de la Fuente, quiso salvar la documentación aragonesa para su patria chica, exponiendo a la Dirección General de Instrucción Pública, en un escrito de 04.06 .1868 "que las riquezas históricas del Reino deben quedar en el país mismo, siempre que haya posibilidad de conservarlas en ël".

A pesar del apoyo de la Junta de Archivos, Bibliotecas y Museos a la idea de Vicente de la Fuente, apoyo que se concretó en la petición de creación del «Archivo del Reino de Aragón» al Ministerio de Fomento, la caída de Isabel II en chivo del Reino de Aragón al 668 hizo que todo aquello qu

De este modo, la incautación de los archivos siguió adelante y el 05.02.1869 De este modo, la incautación de los archivos siguió adelante y el 05.02.1869
se dio por terminada la operación tanto en Zaragoza como en toda la provincia. Ante las noticias del gran valor histórico de los Archivos de las iglesias de Santa María y del Santo Sepulcro de Calatayud, se dispuso el traslado de sus fondos al de San Juan de los Panetes de Zaragoza, junto con los demás archivos de esta ciudad, en un intento más de crear ese gran Archivo de Aragón a que todos aspiraban. Las Diputaciones de Teruel y Huesca se mostraron dispuestas a cooperar en el proyecto.

En plena República (1873), el Gobierno, de acuerdo con la propuesta de la En plena República (1873), el Gobierno, de acuerdo con la propuesta de la
Dirección General de Instrucción Pública, dictó una resolución creando el «Archivo del Reino de Aragón». No obstante, todo quedó en proyecto.

La documentación de iglesias y monasterios que se hallaba retenida, sin mandar al Archivo Histórico Nacional, fue definitivamente expoliada por Real Orden de 01.10.1898 en la que se disponía que las Delegaciones de Hacienda entregasen la documentación recogida.

Sin embargo, según señala Dña. Conchita de la Fuente, "es muy posible que la documentación de la Colegiata de Santa María se envíase unos años antes al Archivo de Alcalá de Henares, antecedente del Archivo Histórico Nacional, ya que la Colegiata del Sepulcro se encontraba en aquel centro en 1882 y parece lógico que se llevase alli conjuntamente con la de Santa María".

${ }^{12}$ Datos cedidos por D. Félix Uriel, Abad de la Colegiata de Santa María, a quien le fueron a su vez suministrados por Dña. Conchita de la Fuente (Madrid, 28.10.1984), del Archivo Histórico Nacional. 
Como puede apreciarse, la historia de la iglesia del Santo Sepulcro estuvo ineludiblemente unida a la de la colegial de Santa María, en una constante relación de - como bien se comprende entre hermanos- disputas y acercamientos, hasta que, a principios del siglo $X X$, se alcanzó una beneficiosa y fraternal puesta en común por escrito de fines e intereses, mediante una "concordia» establecida entre ambos cabildos. En la práctica sin embargo, dicha concordia ${ }^{13}$ iba a significar una pérdida de anteriores prerrogativas por parte del capítulo del Santo Sepulcro ${ }^{14}$.

En la actualidad, a pesar de que desconocemos la existencia de documentación específicamente musical en el citado Archivo Histórico Nacional sí se conserva abundante documentación de carácter general en dicho archivo de la capital de España, procedente de la bilbilitana Colegiata del Santo Sepulcro, según consta por unos «Documentos que existen en el Archivo Histórico Nacional pertenecientes a la Real Colegiata del Santo Sepulcro de Calatayud» ${ }^{15}$ :

\section{Documentos: \\ Reales 162. siglos XI al XVIII. \\ Eclesiásticos 20. siglos XIV \\ al XIX. 642. \\ Particulares 460 . siglos XIII al XVI. \\ Documentos sin sello: \\ Reales 57. 1125-1612. \\ Eclesiásticos 112. 1156-1804 \\ Particulares 730. 1150-1757 \\ Aparte Varios de Valencia: \\ Reales 1. 1503. \\ Eclesiásticos 7. 1503-1542. \\ Particulares 115. 1389-1631.}

Legajos:

${ }^{13}$ El 16.11.1901, se estableció una "Concordia" entre el cabildo de Santa María y el capítulo del Santo Sepulcro, en virtud de la cual, "ambos Cabildos [que establecen su «Hermandad»] se obligan a asistir [juntos] a las solemnidades del Santo Sepulcro, Asunción de la Virgen Maria [sus respectivos titulares], procesión de la Octava del Corpus, Viáticos y funerales de los Capitulares, y demás que en la misma [concordia estipulada por escrito] se prescribe", (Bases aprobadas por el Excmo. é llmo. Sr. Dr. D. Juan Soldevila y Romero, Obispo de Tarazona, para la Concordia establecida entre los Cabildos de las Colegiatas de Santa María y Santo Sepulcro de Calatayud, el día 21 de Noviembre de 1901).

${ }^{14}$ En la mencionada concordia, el capítulo de Santa Maria siempre precedía, tanto en las procesiones como en las funciones oficiales y extraordinarias, al del Santo Sepulcro, "en consideración a la antigüedad de la Colegiata de Santa María, y ser la Iglesia principal". Por otro lado, de interés para nosotros en materia musical, en el apartado sexto de las bases de dicha concordia, se refiere que "a fin de solemnizar las funciones en que concurren los dos Cabildos, dándoles el mayor explendor [sic.] posible, será obligatoria la asistencia de ambas capillas-música, en las fiestas de los Titulares y demás que se detera in 's

${ }_{15}$ Relación cedida por el último Prior de la Colegiata del Santo Sepulcro, D. Jacinto Alcoitia.
- Cabreos relativos a los bienes y hacienda de la Colegiata del Sto. Sepulcro de Calatayud, siglos XVI y XVII.

Cuatro volúmenes en papel folio.

Sección de códices y manuscritos... 820-B a 823-B.

Receptas hechas por Doña Teresa Bruna de Rueyo, Marquesa de San Martín, arrendadora de las Generalidades del reino de Aragón por aumento de su marido $D$. José Alberto Tudela y Lanuza, desde 20 de Fnero de 1696 a 19 de Enero de 1697. Un volumen manuscrito folio mayor... 928-B.

- Memorias de las Fundaciones de misas rezadas y aniversarios de sus reducciones y de los motivos urgentes para pedir una nueva reducción, Manuscritos -folio- 782-B.

Repertorium rerum quæ in sexaginta novem libris in Archivo regii majoricæ reconditis reperiuntur jussu majestatis Philipi III, factum a Michæle Miralles Palmæ Bilarizum 27 mai 1612

Manuscritos folio $781-\mathrm{B}$.

- Relación de las diligencias hechas en la Real Cámara de Castilla en defensa del Patronato de las Vicarías del Sto. Sepulcro., Nuévalos, Tobed, Codos, Torralba, Santa Cruz, Inoges y Aldehuela de Tobed. Año 1760 y siguientes -Manuscritos folio. 786-B.

- Libro de los acuerdos del Cabildo sobre los legados de huérfanas y estudiantes. Manuscritos folio 785-B.

- Libro de caja de la tesorería de la primera cruzada del reino de Aragón administrada por Ambrosio de Oloriz, siendo tesorero general de ella Dn José Alberto Tudela de Lanuza. Años 1692-1696. Consta de 490 páginas. Manuscritos folio. 1784-B. - Libro de la Real y Patrimonial visita de Mallorca que hizo por orden y comisión particular de su Magestad en todo aquel reino y sus islas adyacentes Menorca e Ibiza, Don Juan Villaragut, Virrey y Capitán General.

Consta de 124 folios. Al principio hay un resumen de lo contenido en este libro $y$ al final unas advertencias para conservar y aumentar la hacienda que el Monarca tiene en Mallorca y sus islas. Manuscritos folio siglo XVII. $787 \mathrm{~B}$.

- Libro de procesos eclesiásticos seguidos ante la curia arzobispal de Zaragoza en el siglo XVII. Manuscritos folio 780-B.

- Liber de gestis Capituli Ecclesiæ et Domus Sancti Sepulchri civitatis Calatayubii. 1621-1782.

Manuscritos en papel, folio pergamino. 810-B.

Memorias y Noticias halladas y sacadas de los papeles del Archivo de la Orden Al final hay una lista de los Priores regulares y seculares hasta el siglo XV. Manuscritos en $4^{\circ}$. 827-B.

-Cuaderno de los Treudos de Borja, pertenecientes al priorato del Santísimo Sepulcro de Calatayud. Manuscritos en $4^{\circ}, 852 \mathrm{~B}$.

- Libro de procesos del siglo XVII. Manuscritos en $4^{\circ} \sin$ cubierta. 826-B.

Copia del proceso original hecho en la corte del Justicia de Aragón super aprehensioni Loci de Asso in articulo proprietate existente. Siglo XVII consta de 1065 folios. Manuscrito folio. 783-B. Libro de visita y confrontaciones de todas las propiedades del oficio de los aniversarios hecho por el Sub-prior Mosén Juan Salabert. Año 1514. Folio pergamino manuscrito 890-B. 
- Cabreo viejo. Comprendía las rentas de los cuatro oficios. Priorato. Aniversarios, Tabs y Vicarios. Sólo se conservan dos hojas correspondientes al Priorato y parte de la Vicaría. Siglo XVI. Folio pergamino manuscritos. 891-B.

y parte de la Vicaria. Siglo $X$. Folio pergamino al $4 \%$ subsidio y escusado de las - Documentos impresos manuscritos referente

Un volumen folio Pergamino.

- Litteræ administrationis Domus. Asuntos varios. Cartas relativas a cuentas de la Colegiata. En medio del libro versos curiosos. Manuscritos en papel folio pergamino.

-Tabla genealógica de los Diez de Aux y memorial al rey sobre la nobleza de este linaje y servicios prestados. Un volumen folio, pergamino. Manuscritos e impresos. Siglo XVIII. Procede de Alcalá de Henares. 826-B.

presos. Siglo XVIII. Procede de Alcalá de Henares. 826-B. - Cinco libros de Reales cédulas y otros documentos curiosos relaivos a los méritos y servicios de Don Juan Bitrián de Beaumont. Cada libro tiene su papeleta. I.-159B. volúmenes manuscritos, original $8^{\circ} .888 \mathrm{~B}$

-Treinta reales cédulas para D. Juan Bitrián de Beaumont o Viamonte como Gobernador de La Habana y presidente de Santo Domingo, y comunicaciones ofiiales de la mismá épa. Autógrafos y sellos.

1615-1641. Un volumen folio pergamino. $1105 \mathrm{~B}$.

- Cuatro cédulas de Felipe IV sobre toma del hábito de Calatrava en favor de D. Juan Bitrián de Viamonte y Navarra y testimonios de la toma de hábito y nombramiento de asesor del Santo Oficio del Tribunal de Zaragoza; autógrafo y sellos, 1624. Un volumen folio pergamino. 892-B.

- Papeles de servicios y mercedes de lugares del presidente D. Juan Bitrián de Viamonte (Beaumont) y Navarra.

Hay autógrafos del principe Filiberto de Osange, del Archiduque Alberto de Hay autógrafos Austria, de Reyes españoles, un sello de Carlos I, de Eugenio V de Alemania y los cuarteles de los Beaumont, Navarra, Bitrián de Sobrarbe, ortunios de la $\mathrm{Na}$ varra baja, Ximénez de Aragüés, de Jaca, Pujadas de Figueras, malos, de Molina y Luvxanes. Siglo XVI. Un volumen folio, pergamino. 889-B.

- Servicios y papeles de Don Juan Bitrián de Viamonte o Beaumont de la Orden de Calatrava, desde el año 1607 hasta el de 1648. Un volumen, folio pergamino 887-P. Procede de Alcalá.

Por otro lado, en la actualidad, la gran mayoría de la documentación auxiliar anterior al siglo XVIII (así como, acaso, alguna música que pueda pueda existir de dicho período) procedente de la iglesia colegial del Santo Sepulcro, se encuentra depositada en el obispado de Tarazona, como consta por una «Relación de fondos archivísticos, Biblioteca y Libros de Coro que la Parroquia del Santo Sepulcro de Calatayud, provincia de Zaragoza y diócesis de Tarazona, tiene depositados en el Archivo Histórico Diocesano de Tarazona (Zaragoza) "16.

${ }^{16}$ Ibid. La mencionada Relación..., consta de 14 folios numerados, mecanografiados, con la expresión I6 Ibid. La mencionada Relación..., consta de 14 folios numerados, mecanografiados, con la libros, carpetas, legajos, etc., ahí depositados. Viene firmada a "Ocho de Febrero de Mil Novecientos Ochenta y
De interés musical, según esta relación o índice, se anota ahí la existencia de nada menos que 36 libros de coro - sin duda, monódicos-; libros de actas capitulares (1780), de cuentas o de la fábrica (1792-1812), etc.; breviarios impresos, constituciones de la iglesia..., y una entrada que dice "Villancicos» (a falta de comprobación directa, posiblemente textos impresos), así como varias carpetas con legajos, cartas, memoriales, recibos, procesos, cuentas, pleitos, fundaciones, sentencias, padrones, inventarios, edictos de oposiciones... y otra entrada con "un trozo de pergamino del Cantoral de Antífonas según el rito de la Iglesia de Tarazona"17.

Pero, en todo caso, nos centraremos ahora en los fondos conservados "en" la iglesia colegial del Santo Sepulcro. Dentro de este apartado, merece mención destacada la pequeña aunque interesantísima colección de instrumentos ahí conservados, que encontramos al comienzo de la fase de catalogación del archivo, y que ya han sido convenientemente catalogados y estudiados ${ }^{18}$. Se trata de tres valiosas chirimías tiple datadas hacia el año 1800 (instrumentos de viento-madera elaborados por el maestro constructor catalán Oms, de Barcelona) ${ }^{19}$, un fagot (salido del taller del célebre constructor Adler de París, 1830c),

Dos. Fdo:: Manuel Tello, Director del A.H.D. Tarazona (Zaragoza); Fdo.: Jacinto Alcoitía, Párroco del Santo Sepulcro de Calatayud (Zaragoza) [P.O., Manuel Magdalena]".

${ }^{17}$ Es nuestra intención continuar el trabajo con la catalogación exhaustiva de este mismo tipo de materiales, que, procedentes de la iglesia del Santo Sepulcro de Calatayud, se conserven tanto en el obispado de Tarazona (Archivo Histórico Diocesano), como en el Archivo Histórico Nacional de Madrid. 18 Vid.: EZOUERRO, Antonio: "Chirimía (2)", en El espejo de nuestra historia la diocesis de Zaragoza través de los siglos Zaragoza, Arzobispado-Ayuntamiento (catálogo de la exposición), 1992 Zaragoza a "Calatayud Archivos Musicales de" 1997, pp 69-72 BORRÀS, Josep y EZOUERRO, Antonio: "OMS. Dos Chirimín" "OMS Chirimin",

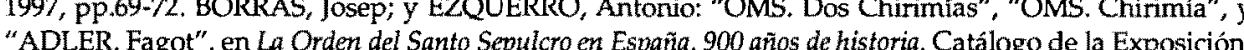
ADLE. Zaragoza, Diputacion de Z ragoza, 199, pp.147, 148 y 152, respectivamente. EZQUERRO, Antonio; PAVIA, Josep: Polifonia de facistol en la Colegiala de Santa Maria de Calatayud (Zaragoza). Zaragoza, Institución Josep; y EZQUERR, Antonio: "Chirimias en Calatayud. Principioy hinal de un proceso constructivo" En: Revista de Musicologia, XXII, ${ }^{2}, 199$, en dicho articulo se ofrecen los planos levantados de los instrumentos, realizados con vistas a la posible construcción de copias fidedignas que poder utilizar en conciertos y audiciones de musica práctica, atendiendo al desde hace ya tiempo en boga concepto de Auffithrungspraxis, o práctica de la música interpretada con instrumentos de época y criterios de rigor histórico] 19 Sobre instrumentos "históricos" españoles, y en particular sobre chirimías, bajones y fagotes, puede consultarse, entre una amplia bibliografía, algunos de los trabajos citados en: BORRÁS, Josep y EZQUERRO, Antonio: "Chirimía en Calatayud... ", Op.cit., así como, por ejemplo: KENYON, Beryl "El primer oboe español que formó parte de la Real Capilla: don Manuel Cavazza". En: Revista de Musicologia, VII, $n^{a}$ 2, 1984, pp. 431-434. Ibid.: "The wind-instrument maker Bartolomé de Selma (+1616), his family and workshop". En; Galpin Society Journal, XXXIX, 1986, pp. 21-34. Ibid.: "Instrumentos e instrumentistas españoles y extranjeros en la Real Capilla desde 1701 hasta 1749". En: España en la Música de Occidente, II, Madrid, 1987, pp. 93-97. Ibid.: "La importación de instrumentos de viento de Inglaterra durante la segunda mitad del siglo XVI". En: Nassarre, IV, $\mathrm{n}^{\circ}$ 1-2, 1988, pp. 141-144. Ibid.: "A late 16th-century portrayal of the jointed dulcian", En: Galpin Society Journal, XLIII, 1990, pp. 150-153. 
las cañas que estuvieron en uso correspondientes a todos ellos, una caja-estuche para el fagot, y otro antiguo estuche de violín. Todos ellos fueron hallados en bastante buen estado de conservación, de modo que los instrumentos todavía pueden hacerse sonar. A excepción del estuche de violín y la tercera chirimía - con llave metálica-, que aparecieron posteriormente, los restantes instrumentos aparecieron guardados tal y como debían de estar preparados para su uso cotidiano, en la caja del ministril correspondiente, incluyendo en su interior una cajita metálica que contenía las embocaduras y lengüetas de caña, con cordel untado en sebo, para las dos chirimías y el fagot ${ }^{20}$.

El conjunto formado por las tres chirimías ${ }^{21}$, sin duda los elementos más valiosos de la colección, es, hasta donde conocemos, el único de estas características conocido hasta la fecha en Aragón, junto a otra chirimía, de fecha anterior (muy probablemente del siglo XVII), que se conserva en el Museo Diocesano de Arte Sacro de esta misma ciudad y que perteneció a la capilla de música de la hermana Colegiata de Santa María ${ }^{22}$

Hasta donde conocemos por el momento, las tres chirimías de la íglesia del Santo Sepulcro constituyen, junto a una pieza del Museo de la Música de Barcelona, los únicos ejemplares de su especie construidos en dos piezas que se conservan en España (generalmente se construían en una sola pieza), y por tanto, son unos ejemplares valiosísimos para el estudio organológico de este tipo de instrumentos de viento-madera y doble lengüeta, podría decirse que incluso a nivel internacional. El hecho de que su decoración se realice con materiales como el hueso o el marfil, y que una de ellas, de manera excepcional, presente una llave de latón, síntoma ya de su construcción tardía, la cual adelanta ya y recoge procedimientos constructivos más propios de los oboes, -instrumentos tradicionalmente considerados como los sucesores de las chi-

${ }^{20}$ EZQUERRO, Antonio: "Chirimía (2)", en El espejo de nuestra historia..., Op.cit., p. 331. [En la cajita metálica aparecieron también algunas cañas para clarinete].

${ }^{21}$ Cfr.: BORRÀS, Josep; y EZQUERRO, Antonio: "Chirimías en Calatayud... ", Op.cit.

${ }^{22}$ Entre los fondos musicales de los archivos eclesiásticos de Calatayud, y más concretamente en el Archivo de Música de la Colegiata de Santa María, se conserva actualmente un único y pequeño ejemplo manuscrito de literatura para chirimías, que podríamos calificar como poco representativo de lo que este instrumento debió significar, a pesar de que, el mero hecho de haber quedado dicho ejemlo que este instrumento debió significar, a pesar de que, el mero hecho de haber quedado dicho ejemplo, sea en sí mismo un testimonio de cierto valor. Coincide con los pequeños pasajes publicados por Angel MINGOTE en su Cancionero de la Provincia de Zaragoza (Zaragoza, Institución "Fernando el Católico", 1950), aunque pertenece al género de música procesional, casi popular, a modo de pasacalles, a partir de una melodía sencilla y un esquema rítmico repetitivo apenas basado en pequeñisimas variaciones ornamentales. Por lo que respecta a la recepción de la música antigua, llama la atención encerado en uso practicaSanta y el fagot, en la Colegiata del Santo Sepulcro. rimías, a las que suplantaron en nuestros templos y orquestas-, denota que el encargante de estos instrumentos (¿el propio cabildo del Santo Sepulcro?, ¿algún caballero de la Orden, como regalo para la colegiata?), deseaba contar con unos instrumentos de lujo, y que, sin duda, no habría reparado en gastos a la hora de su adquisición - y acaso, encargo-, a pesar de lo anacrónico de la existencia de estos instrumentos ya para comienzos del siglo XIX, cuando los mencionados oboes hacía tiempo que habían penetrado en las capillas musicales de toda Europa, y las chirimías - anteriormente instrumentos fundamentales en los conjuntos instrumentales de los siglos XVI y XVII- habian llegado casi a desaparecer, relegadas al ámbito de la música popular (pasacalles, procesiones, festejos públicos), a las solemnidades o funciones de algunos ayuntamientos (en conjunción con trompetas y atabales), o, únicamente en España - pues en el resto de Europa hacía ya tiempo que habian desaparecido de su uso en la práctica-, a las capillas musicales eclesiásticas, en las que, como ya dijimos, incluso se encontraba también ya su uso en franca regresión, en favor de otros instrumentos como los oboes, y aun los clarinetes.

\section{**}

\section{LOS CÓDICES DEL ARCHIVO DE MÚSICA}

Por lo que respecta a la documentación musical del rico archivo de esta iglesia colegial, existen dos copias (una de ellas completa, en 4 volúmenes, y otra, de la que sólo quedan tres volúmenes) del pasionario impreso en Zaragoza en 1612 por Juan de Lanaja y Quartanet, titulado Opvs Harmonicvm / In Historia Passio- / nis Christi a Qvatvor / Evangelistis conscripta, / in lamentationibus, et / Cantorvm tvrba, / Iuxta optimam MVSICA Rationem, ac noui Missalis, Vulgatæq; / Editionis fidem, Sixti Quinti, \& Clementis Octaui Summor. PP. / auctoritate restitutam; ad excitandam Christianam / Pietatem compositum \& concinnatum. / Collectore R. P. Fr. Ioanne Sanchez ab Azpeleta / Ordinis Seraphici P. S. Francisci. / Excellentissimo D. D. Petro Manrique Archiepiscopo / Cæsaraugustano Dicatum et Consecratum. / Anno [aquí se intercala un escudo episcopal] 1612. / Cum licentia \& Priulegio. / CASARAVGVSTAE, / Apud Ioannem a Lanaja \& Quartanet. / A costa de Pedro Lorente Aguado de Pereda ${ }^{23}$.

${ }^{23} \mathrm{De} 330 \times 230 \mathrm{~mm}$., recoge diversas pasiones de compositor desconocido. Algunos de estos volúmenes, en pliegos de papel cosidos, llevan tapas forradas en pergamino, y han sido reparados reformente del siglo XVI. Registran además diversas anotaciones manuscritas de cantores de la capilla y 
Los contenidos de este Pasionario impreso ${ }^{24}$, que, como se desprende de los ejemplares bilbilitanos, debió ser profusamente utilizado en la colegial del Santo Sepulcro, y del que se conservan otras copias en diferentes archivos de la actual comunidad autónoma, dan buena cuenta de la importancia que revistió la obra para el antiguo Reino de Aragón, tanto desde el punto de vista religioso y sociopolítico, como desde el estrictamente musical ${ }^{25}$

Se conservan además en el archivo musical de la iglesia hasta cuatro libros de facistol (de ellos, tres son pasionarios polifónicos) ${ }^{26}$, que recogen algunos ejemplos de obras litúrgicas, muestra de la mejor polifonía de atril renacentista europea - de la escuela romana, e hispana- (de G. P. da Palestrina, Francisco Guerrero, T. L. de Victoria, Rodrigo de Ceballos...), así como de otros compositores ya plenamente del siglo XVII, de producción más local, tales como Juan Ramos, o el maestro Cáseda. Son los siguientes:

algunos caballeros de la Orden: "Para Miguel de liz"; "El Marques de Aytona Lugarteniente General"; "Fermin Ciria"; "Juan"; "Miguel de Lizaga Contralto / del S.to Sepulcro de Calatayud / en el año 1686 y 87"; "Digo, io Domingo Joachín Moron / Tiple desta Yglesia del Santo / Sepulchro de Calataiud to / firme de mi Mano a 31 de / Marzo del Año de 1667": "Tan Francisco Ximenez / Tiple del Santo Sepulcro / SSiendo Maestro de Capilla / Miermano Mosen Domingo / Ximenez; en el año de 1697"; "Yo Mulcrol Calisto Yran / zo. tiple del Santo Sepulcro / a 12 de Abril año de 1669"; "Digo yo Domingo Miguel Calisto Yran / zo. tiple del Santo Sepulcro / a 12 de Abril año de $1669^{\prime \prime}$ " "Digo yo Domingo Moron que e/ rrecibido por manos de Pedro / Zabala 60 e por suma de más can / tidad quel dicho me debe pag / ar"; "Dela mano y pluma de Diego Calbete / 1667"; "Dela mano y pluma de Pedro Be-

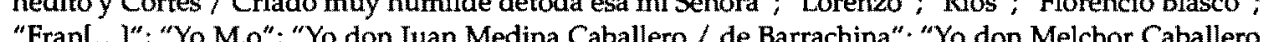

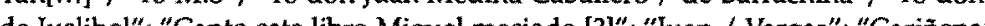
e Jus " Canto este libro Miguel meçiado [?]" "Juan / Vargas" " "Cariñena".

${ }^{24}$ Aparte de la música, comprende: $I$ ) Licencia de "D. Thomas de Borja Arçobispo de Caragoça", firmada En "Zaragoça a 4. de Deziembre de MDCX" ( "Por mandado de su Senoria lllustrissima, losephus de Chiriugaw); IIf Licencia del Marques de Aytona, Don Gastón de Moncada (también Conde de Osona, Vizonde de Bas y Cabrera, Gran Senescal de Aragon, Lugarteniente y Capitan General en el Reino de Arag riam", (Petro Pol IV), II Nota prelliminar de Pedro Sánchez de Azpeleta al arzobispo de Zaragoza Pedro Manrique; IV) [Colofón impreso:] "Cæsaravgustæ. / Apud loannem a Lanaja \& Quartanet, / anno Domini, 1612. / [y añadido ms.: "MDCXII.»] [a continuación, se inserta un florero, grabado]"

${ }^{25}$ Comprende: 1.- Dominica Palmarum: "Passio Domini nostri Jesu Christi secundum Matthæum"; 2.- Feria III: "Passio Domini nostri Jesu Christi secundum Marcum"; 3.- Feria IV: "Passio Domini... secundum Lucam"; 4.- Feria VI: Passio Domini... secundum Johannem"; 5.- Feria V: Lamentationes, Lectio I: "Incipit lamentatio Jeremiæ prophetæ. Aleph. Quomodo sedet sola"; 6.- Lectio II: "Vau. Et egressus est"; 7." Lectio III: "Jod. Manum suam"; 8.- Feria VI: Lamentationes, Lectio I: "De lamentatione Jeremiæ prophetæ. Heth. Cogitavit Dominus"; 9.- Lectio II: "Lamed. Matribus suis"; 10.- Lectio III: "Aleph. Ego vir videns"; 11.- Sabbatho Sancto: Lamentationes, Lectio I: "De lamentatione Jeremiæ prophetæ. Heth. Misericordiæ Domini"; 12.- Lectio II: "Aleph. Quomodo obscuratum est"; 13.- Lectio III: "Incipit oratio Jeremiæ prophetæ. Recordare Domine"; 14.- Sabbatho Sancto: In vigilia Resurrectionis Domini ad benedictione cerei: "Exultet iam angelica turba coelorum".

${ }^{26}$ Todos estos pasionarios debieron ser cantados anualmente, y utilizados a menudo, a juzgar por las numerosas anotaciones manuscritas de los cantores de la capilla e infantes de coro que aparecen en ellos.
LIBRO DE ATRIL (Ms.1): Ms. S. XVIII ${ }^{27}$. Contiene ${ }^{28}$ :

1: Missa "Ecce Saccerdos Magnus" de $5^{\circ}$ punto alto, de CÁseda para S, A, T B (fols. 1v.-25r.); consta de Kyrie, Gloria, Credo, Sanctus y Agnus Dei. 2: Missa de 3. tono de ÇABAllos para S, A, T, B (fols. 26v.-46r.); consta de Kyrie, Gloria, Credo, Sanctus y Agnus Dei. 3: Missa de $4^{o}$ tono de VICroria para S. A, T, B (fols. 47v.-67r.); consta de Kyrie, Gloria, Credo, Sanctus y Agnus Dei. 4: Missa sobre el Canto de $8^{\circ}$ tono, de GUERRERo para S, A, T, B (fols. 68v.-88r.); consta de Kyrie, Gloria, Credo, Sanctus y Agnus Dei. 5: Missa "O Regem Creli" de Palestina para S, A, T, B (fols. 89v.-120r.); consta de Kyrie, Gloria, Credo, Sanctus y Agnus Dei. 6: Missa "Jam Christus Astra Ascenderat", [ANónIMA] para S, A, T, B (fols. 121v.-134v.); consta de Kyrie, Gloria, Sanctus y Agnus Dei.

LIBRo DE ATRIL (Ms.2): Ms. S. XVIII' ${ }^{29}$. Contiene:

1: Passio Dominice Palmarum [Pasión según San Mateo] [ANONIMA] para S, A, T, B (fols. 1v.-75r.). 2: [Passio] Feria Sexta [Pasión según San Juan] [ANónIMA] para S, A, T, B (fols. 75v-130r.).

LIBRO DE ATRIL (Ms.3): Ms. S. XVIII ${ }^{30}$. Contiene:

1: Passio Dominice Palmarum [Pasión según San Mateo], ANónima [Simón Alegre] para S, A, T, B (fols. 1v.20r.). 2: Passio Ad Feriam Tertiam [Pasión según San Marcos], ANONIMA [SIMÓN ALEGRE] para S, A, T, B (se incluye, aparte, una partichela de tenor); (fols. 21v.-36r). 3: Passio Ad Feriam IV [Pasión según San Lucas], ANoNIMA [SIMÓN ALEGRE] para S, A, T, B (se incluye, aparte, una partichela de tenor); (fols. 37v.-50r.). 4: Passio Ad Feriam VI [Pasión según San Juan], ANÓNIMA [SIMON ALEGRE] para S, A, T, B (se incluyen, aparte, dos partichelas de tenor); (fols. 51v.64r.). 5: Missa In Adventum Et Ouadragessi, ANÓNIMA [SIMON ALEGRE] paraS, A T B (fols. 65v.68r.); contiene Kyrie, Sanctus, Benedictus y Agnus Dei. 6: Ad Proces-

${ }^{27}$ Tapas de madera forradas en piel, con 8 clavos en la tapa y contratapa, herrajes y cierre de hierro. Papel; 134 fols. numerados; tinta negra, y roja en algunos títulos y capitales. Aparecen en blanco los siguientes folios: 25v-26r.; $46 \mathrm{v}$. $47 \mathrm{r}$; $67 \mathrm{v}-68 \mathrm{rr} ; 88 \mathrm{v} .89 \mathrm{r} ;$ y $120 \mathrm{v} .-121 \mathrm{r}$.

${ }^{28}$ A lo largo de todo este trabajo, utilizamos las abreviaturas para voces e instrumentos adoptadas por RISM-internacional. Todo lo que se anota entre corchetes, no se toma directamente de la fuente, sino que es aportación nuestra.

${ }^{29}$ Tapas de madera forradas en piel, y restos de ataduras, también en piel. Papel, 130 fols. numerados; tinta negra, y roja en algunos títulos y capitales. Para proteger la contratapa se ha pegado una hoja numerada con el "61" de un fragmento polifónico de otro libro de atril, sin texto (S. XVII-XVIII con las partes de contralto y de bajo). Fol. 1r., en blanco. Notas de infantes en cara interna de la tapa y fol.1r. y 130v: se cita a Mariano Santos como Maestro de Capilla del Santo Sepulcro; Eusebio Royo, músico; Joaquín Bargas, tiple; Nicolás Santos, tiple; Manuel Aramburo, tiple $2^{\circ}$; Joaquín Sigüenza; Domingo Ramos; Cornelio Cornelini; Santos Pedro.

${ }^{30}$ Tapas de cartón forradas en piel; cosido. Papel, 81 fols. numerados (el folio 81 , pegado a la contratapa); tinta negra, y roja en algunos títulos y capitales. Copista y autor, Simón Alacre [sic. "Simón Alegre"]: «Hic liber factus fuit a Simone Alacre. Musicus Santi Sepulchin. "Es de / antar pasio en presbiterio Aparte, hay una pas de canto panuel Matín. Aparen en $50 v-51 r$; $64 v$. con pentagramas vacíos - 65r.; y $68 v-69$ r. 
sionem Dominice Palmarum "Gloria Laus Et Honor", [Himno], ANONIMO [SIMON ALEGRE] para S, A, T, B (fols. 69v.-77r.). 7: Antifona "Regina Cali Latare", ANÓNIMA [SimÓN ALEGRE] para S, A, T, B (fols. 77v.78r.). 8: Alleluia "Portare Quia Quem Meruisti", ANÓNIMO [SIMÓN ALEGRE] (fols. 78v--81r.; el fol. 80, roto). [Continuación del Regina cœeli].

Libro De ATRIL (Ms.4): Ms. S. XVII ${ }^{31}$. Contiene:

1: Passio. Dominice Palmarum a 4. [Pasión según San Mateo] [ANONIMA] para S, A T, B (fols. 0v.-37r.) 32. 2: Biernes Santo. [Pasión según San Juan] [ANONIMA] para $S$,

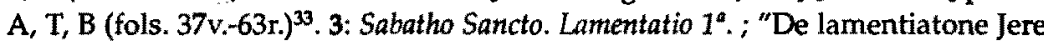
miæ Prophetæ Heth Misericordiæ Domini"; [ANONIMA] para S, A, T, B (fols. 63v.68r. $)^{34}$. 4: Feria Sexta. Lamentatio "De lamentatione Jeremiæ Prophetæ Heth Cogitavit Dominus"; [ANONIMA] para S, A, T, B (fols. 69v.-72r.). 5: Feria 6a. Lamentatio 1a, a 6, de JUAN RAMOS para S 1, 2 A 1, 2 T B (fols 72v-78r) 35. 6: "Quo vulneratus in su, de JuAN RAMOs para $1,2, A 1,2, T$, B (foll: in supermucrone diro lancea ut nos hoare". [ANONMA] para A, $\mathrm{T}$ (fols. 81v.-82r.). [Estrofa del Himno Vexilla regis]. 7: "O beatum apostulum qui inter primos electus".
[ANONIMA] para B (fol. 82v.).

Aparte de los cuatro volúmenes indicados, no hace muchos años se conservaba al parecer en la colegial del Sepulcro otro libro, que en la actualidad no hemos podido localizar, casi con toda seguridad debido a que habría sido llevado con el resto de la documentación de la colegiata, y junto a los cantorales gregorianos y otros códices de cantollano, al Archivo Histórico Diocesano de Tarazona. De él podemos ofrecer al menos el resumen de su contenido, gracias a los datos amablemente cedidos por D. Pedro Calahorra ${ }^{36}$. Es el siguiente:

${ }^{31}$ Tapas de cartón forradas en piel; encuademado cosido; borde inferior derecho, muy deteriorado Papel, 83 fols. numerados (contiene 2 fols. sin numerar al principio: I: con anotaciones de los infantes, y II: fol. al que llamaremos fol. 0. El fol. 83r.-v., en blanco); tinta negra, y roja en algunos adomos en forma de flor. Incluye una "Tabla de los que cantaron el Passio el año de 1787: Los que asistían a la CapiIla: Miguel Palacín y Cabrero, Maestro de Capilla; Francisco Oliac, bajonista y $1^{\circ}$ músico; Josef Contre ras bajonista y $2^{\circ}$ músico; Manuel Gómez, tenor y $3^{\circ}$ músico; Simón Alegre, contralto y $4^{\circ}$ músico; Antonio Lloro, contralto y $5^{\circ}$ músico; infantes: Antonio Gómez, $1^{\circ}$ infante; Pedro Utrilla, $2^{\circ}$ infante; Joaquín Cosuenda, $3^{\circ}$ infante; y Pascual Cosuenda, $4^{\circ}$ infantem. Fol. 83: lleva anotaciones de los infante y listados de la capilla en el S. XVIII: "Jayme Vitrian, Maestro; Francisco Oliac, bajonista $1^{\circ}$; Joseph Contreras, bajonista $2^{\circ}$; Lorenzo Montuenga, tiple; Joseph Romanillos, tiple; Juan de Funes, tiple; Joseph Labana [?], contralto; Simón Alegre, contralto; ]oseph Cases, tenor; Manuel Gillermo, tenor»' [1777c]. Algunos folios, deteriorados, presentan roturas: fols. 69-78 y 81-82. Los folios 79 y 80 no existen -han debido de ser cortados-. Otros, presentan pentagramas vacíos: fols. 68v-69r., 78v, y 81r.

${ }^{32} \mathrm{El}$ “Contra sepulchrum", a 4 y a 8 voces.

${ }^{33} \mathrm{El}$ «In quem transfixerunt», a 8 voces.

${ }^{34}$ Tiene secciones a 3 y a 5 voces.

${ }^{35}$ Tiene secciones a 4 y a 6 voces.

${ }^{36}$ Nuestro agradecimiento a D. Pedro Calahorra, verdadero impulsor del proyecto de catalogación y estudio de los archivos musicales de Calatayud que coordinamos. Sin él, no hubiera sido posible nuestro trabajo. Asimismo, agradecemos todo el apoyo institucional prestado por el anterior director
CórCE 1: "Emanuel Mendez. Faciebat año 1758". Contiene:

1: Domin. per anum. Fol.1v. ("Asperges me Domine hisopo"). S, A, T, B. 2; Tempore Paschali. 8t. Fol.4v. ("Vidi aquam" ("Egredientem de templo"). S, A, T, B. 3: In festo B. M. ad Nives. Hym. 1t. Fol.8v. ("Ave maris stella"). S, A, T, B. 4: Hymnus Sancti Ambrosii, e Augustinus. 4t. Fol.10v. ([Te Deum laudamus] "Te Dominum confitemur"). S, A, T, B. 5: Salve B. V. Maria ad nives. 1t. ${ }^{37}$. Fol.19v. ([Salve Regina mater misericordiæ] "Vita dulcedo"). S, A, T, B. 6: In festo Pentecost. [1" estrofa sólo]. Fol.25v. ("Veni Creator Spiritus"). S, A, T, B. 7: In festo Corp. Christi [5? P. Alto ${ }^{38}$. Fol.27v. ("Pange lingua gloriosi"). S, A, T, B. 8: In Sacratissima Nocte Nativit. Invitat. [4t]. Fol.31v. ("Christus natus est nobis"). S, A, T, B. 9: Missa in Adventum et Quadragessim. [4t]. Fol.32v. ("Kyrie eleison"). S, A, T, B. Et incarnatus, fol.33v, S 1, 2, A, T; Sanctus, S, A, T, B; Benedictus, S, A, T, B; Agnus Dei, S, A, T, B ("Tertium dona nobis": [Qui tollis]). 10: Magnificat [defunctorum] [7t] [a 5$]^{39}$. Fol.37v. ([Magnificat] "Anima mea Dominum"), S1, 2, A, T, B. •Psalterium compositum per David Regem, quod composuit cum Prophetico Spiritu; sequendo in illo passus siqualires [?] vita sua; ad omnes vestros [?] amicum relig. 11: Dixit Dominus [8t]. Fol.43v. ([Dixit Dominus Domino meo sede a dextris meis] "Donec ponam inimicos") $S$ 1, 2, 3, T, B. 12: Confitebor [7t] [a 4]. Fol.46v. ([Confitebor tibi Domine] "Magna opera Domini"). 13: Beatus vir. 6t. [a 4; Gloria, a 5]. Fol. 49v. ([Beatus vir qui timet Dominum] "Potens in terra erit"). S, A, T, B. 14: Laudate pueri Dominun. 3t. [a 4]. Fol.53v. ([Laudate pueri Dominum laudate nomen Domini] "Sit nomen Domini"). S, A, T, B. 15: Laudate Dominum omnes. 4t. [a 4]. Fol.56v. [Laudate Dominum omnes gentes] "Quoniam confirmata". S 1, 2, A, T. 16: Letatus sum. 7 t. Psalmus 121 [a 4; Propter fratres, a 5; Sicut erat, a 5]. Fol. 57v. (L2ætatus sum in his quæ dicta sunt mihil "Stantes erant pedes nostri"). S, A, T, B. 17: Nisi Dominus edificarit. Psalmus 16 de B. M. [a 4. Sicut sagite, a 5; Cloria Patri, a 5] Fol.61v. ("Nisi Domi-

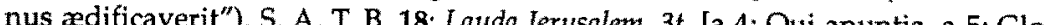

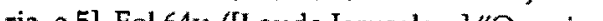
ria, a 5]. Fol.64v. ([Lauda Jerusalem] "Quoniam confortavit"). S, A, T, B. 19: In exitu Israel. Psalm. 113. 3t. [a 4; Qui convertit petram, a 5; Aures habent, a 5; Gloria, a 5]. Fol.68v. ([In exitu Israel de Ægyptol "Facta est Judæa"). S, A, T, B. 20: Beati omnes. 6t. [a 4; Gloria, a 5]. Fol.78v. ([Beati omnes] "Labores"). S, A, T, B. 21: In convertendo. 4t. [a 4; Venientes, a 5]. Fol.83v. ([In convertendo] "Tunc repletum est"). S, A, T, B. 22: Domine probasti me. 3t. [a 5; Si sumpsero, a 4; Et vide si via, a 4]. ([Domine probasti me] "Intellexisti"). S 1, 2, A, T, B. 23: De profundis. 3t. [a 4; Sustinuit, a 5; Et ipse, a 5]. Fol.95v. ([De profundis clamavi] "Fiant aures"). S, A, T, B. 24: Memento Domine. 5t. [a 4; Sacerdotes ejus, a 5; Gloria, a 5]. Fol.99v. ("Memento Domine"). S, A, T, B. 25: Credidi propter. 1t. [a 4; Vota mea, a 5]. Fol.106v. ([Credidi propter quod locutus est] "Ego dixi"). S, A, T, B. 26: Confitebor. 8t. Pun-

de la Institución «Fernando el Católicom, D. Ildefonso Manuel Gil, así como también por su actual director, D. Guillermo Fatás. Y por facilitarnos el trabajo diario, gracias también a D. José Barranco López y a D. Félix Sánchez.

${ }^{37}$ Se trata de la misma pieza que aparece en el cantoral LAMs. 3 de la colegiata de Santa María con el $\mathrm{n}^{\circ} 11$.

La misma pieza que la del cantoral LAMs. 3 de la colegiata de Santa María $n^{\circ} 19$.

${ }^{39}$ Igual al cantoral LA Ms. 3 de la colegiata de Santa María, pieza $n^{\circ} 23$. 
to alto. [a 4]. Fol.109v. ("Confitebor"). S, A, T, B. 27: Super flumina. 6t. [a 4].

Fol.113v. ([Super flumina Babyloniis] "In salicibus"). S, A, T, B.

Por lo demás, existe también en la iglesia un interesante códice de facistol titulado Libro de Magnificas ã $4^{\circ}$. / voces, para la Insigne / Iglesia Colegial del S.to Sep ${ }^{\circ}$ / Escrito por D. $n$ Si- / mon Alegre Con- / tralto de la misma / Año $1808^{40}$.

A lo que todavía cabría añadir algunas ediciones impresas de libros litúrgicos con música en cantollano, de los siglos XVIII y XIX, que enriquecen más aún el archivo y biblioteca de la iglesia, además de otros libros "oficiales" de culto y cuadernillos impresos con inclusión musical, entre diversos misales ${ }^{41}$, breviarios ${ }^{42}$, antifonarios, graduales, rituales, prefacios, semanillas, composiciones varias insertas en los libros de coro, etc ${ }^{43}$.

${ }^{40} \mathrm{Se}$ trata de un libro manuscrito, en papel, con tapas de pergamino y 49 folios numerados -más uno al final [50] sin numerar-. Dispuesto para $S, A, T, B$, consta de una colección de Magníficats por

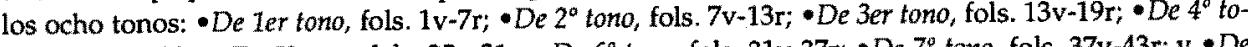
no, fols. 19v-25r; •De $5^{\circ}$ tono, fols. 25v-31r; $\bullet$ De $6^{\circ}$ tono, fols. 31v-37r; $\bullet$ De 7 tono, fols. 37v-43r; y $\bullet$ De $8^{\circ}$ tono, fols. 43v-49r. Pegados en las contratapas, lleva algunos fragmentos impresos del siglo XVI con polifonía, que, a falta de ser retirados, pudieran corresponderse con algunas páginas de los conocidos Magnificats de Sebastián Aguilera de Heredia. El mencionado título del volumen, aparece en el fol.1r. inscrito en una portada decorada: muestra un escudo con la cruz del Santo Sepulcro y una corona sostenida por dos ángeles, y lleva una orla con decoración vegetal -flores-alrededor del escudo, todo ello policromo. Los fols. 49v-[50v], rayados con pentagramas, en blanco.

${ }^{41}$ Missale Romanum Ex decreto sacrosancti Concilii Tridentini restitutum S. Pii V. jussu editum. Clementis VIII. et Urbani VIII. Auctoritate recognitum. Et novis Missis ex Indulto Apostolico hucusque concessis auctum. [grabado del año 1714] Romæ, Typis Sacre Congregationis de Propaganda Fide. Anno M. DCC. XIV. Superiorum Permissu. Se trata de un libro grande (de $420 \times 285 \mathrm{~mm}$.) con tapas de cartón forradas en piel y decorado en oro en tapas y lomo. Lleva un escudo episcopal en ambas tapas. La cuidada edición impresa, incluye numerosos grabados de gran calidad.

42 Breviarium Romanum. Pars Autumnalis. Un libro de $225 \times 153 \mathrm{~mm}$. con tapas de cartón forradas en piel y ribetes geométricos dorados. Lleva unos cierres metálicos, rotos. Le falta la portada, de suer te que comienza con el índice de festividades del mes de Septiembre. En la primera parte del libro aparece asimismo una "Oratio / a Papa Urbano VIII / edita». [Pág. 1:] «Psalterium / Dispositum / pe Hebdomadam. / Cum Ordinario Officii de Tempore. / Pars Autumnalis. / Dominica ad Matutinum. Ante Matutinum, \& omnes Horas, præterquam ad / Completorium, dicitur secreto: / [...]m. Al final del libro impreso, se ha pegado un cuademillo también impreso: «Die III Novembris. / In Festo $S$. Gaudiosi Episc. et / Confessoris. / Oratio. / Deus Sanctorum tuorum splendor / [...] / Ex Actis in Breviario Tyriasonensi exa- / ratis 1541. / Lectio IV. / Gaudiosus natione Hispanus [...]".

${ }_{43}$ Nueva Ilustracion, y Exposicion de los Hymnos mas frequentes en el Breviario Romano. Su autor Don Banifacio Lahoz Maestro de Gramatica en la Villa de Montalvàn. Sacala a luz El Dr. Don Jayme Antonio MuBonifacio Lahoz, Maestro de Gramatica en la Villa de Montador. Juez Synodal de este Arzobispado, y su Visita niessa, Canonigo de la Santa I lesia Metropolitana del Salvador, Je Syuero; tres veces Rector que fue, y actualdor ent la Vacante por muerte del lisitrisimo Señor D. Thomas de Agres, exemplar de Prelados, y Protector mente lo es de la Universidad de Zaragoza, \&c. y lo dedica al Santissimo exemplar de Prelados, y Protector Este libro, hace la exposición (anotada) de cada uno de los himnos, y da su traducción literal. Un libro Exposi / de los / Imnos". Lleva impreso de $200 \times 145 \mathrm{~mm}$., encuadenado en pergamino. Lo Universidad de Zaragoza racionero del Carlos

\section{EL FONDO DE MÚSICA «A PAPELES»}

Entre el mencionado fondo de obras musicales "a papeles" de los siglos XVIII al XX, el principal del archivo, existen - junto también a algunas copias de composiciones del siglo XVII anotadas en época posterior, y aparte numerosas obras anónimas-, un elevado número de composiciones con nombre conocido de autor (según varios antiguos inventarios de finales del siglo XIX ${ }^{44}, \mathrm{y}$ de nuestra propia catalogación). Los compositores con obras en este archivo, ordenados alfabéticamente por su primer apellido, son los siguientes:

Abadía, F. Acthe, Francisco Agüeras González, Antonio Alberdi A., Giovanni Cesane Aldega, Gregorio Allegri, Fermin $M^{a}$ Alvarez, Paolo Amatucci, Diego Amperosa, Francisco Andrevi, Francisco Anel e Izquierdo, Gaspar de Arabaolaza, Miguel Armaudas Larrodé, Bonifazio Asioli da Correggio, Urbano Aspa, A. Balladori, Jose Miga Ballé, M. rencon, Vinenzo Bellini, Simon Benell, Cosme Damin Jose de Benito, Jose Menta Beobide, Simeón Blanquê, Antonino Blasco, Justo Blasco, Fr. Boissière, Ramón Bonet, Charles Bordes, Luigi Bordesse, Ramón Borobia Cetina, Luigi Bottazzo, Francisco Brunet Recasens, C.a, E. C., Alejo Cabello, Enrique Camó, Cándido Candi, P. Carazantes, Benigno Cariñena, Ramón Carnicer Batlle, Juan Carreras, Francisco Cascante, Tomás Castejón, Gonzalo Castrillo, Sergio Cilveti, Juan Capristano Coley, Joseph Concone, Domingo Cuéllar y Altarriba, Ramón Fálix Cuállar y Altarriba José Cumellos Ribó, Manuel Chueca, Manuel Chulun ristisek DrdIa, B. E., Teodoro Apolonio Echegoyen, J. Enviti, Hipólito Escorihuela, Miguel Hilarión EsLava y Elizondo, F. Fantini, Fauconier, José Fayos, Fernández, M. Ferner, Hilario Frágeda, Francesch, B.G., J. G., M. G. y M., H. Gabriel-Marie, Lázaro Gaínza, Emilio Garcés, García, Francisco García, M. Garcia, Mariano Garcia, Luis García Bellés, Francisco Javier García Fajer "El Españoleto", Pablo Garcia de Pamplona, Pietro Generali, Tomás Genovés y Lapetra, Casto Gimeno, J. Gimeno, Román Gimeno lbáñez, Giuseppe Giordani, G. J. Giorgini José Giorgini Pedro Coldtraz, Gonzelez Bravo, Nicoth́s Comzéloz Martinez Angel Gonzalez Viloria, I. Gonzalo, Felipe Gorrill y Osambela, Chanles Gounod, Peter Griesbacher, Rafael Guasch, Guevara, Jesus Guridi Bidaola, Theodore de la Hache, Georg Friedrich Händel, Franz Joseph Haydn, Herluesa, Pablo Hernández Salces, Isidor Hernández, Hidalgo, Antonio Ibáñez, José Ibáñez, Arturo $M^{a}$ de Inchausti, Buenaventura Iñiguez, Ira-

Borromeo, Examinador Sinodal de los Obispados de Jaca, Lérida y Huesca, etc. Otra aprobación: del rvdo. Padre Fray Sebastián Quartero, lector jubilado, ex-guardián de los conventos de Jesús y San Francisco de Zaragoza, ex-cronista de la provincia de Aragón, examinador sinodal del Arzobispado, y calificador del Tribunal de Aragón, y de la Suprema. Licencia del Consejo y Suma de la Tasa: por D. Juan Peñuelas, Secretario de Cámara del Rey; Fe de erratas: por el Licdo. Manuel Licardo de Rivera, Corrector General por S.M.

${ }^{44}$ Existen varios antiguos inventarios datados; los hay del 01.03 .1889 , con renovaciones posteriores del 15.03.1889, 04.05.1889, y 26.11.1889; van firmados por «El Director de la Capilla Serafin Larroca» y por el «Lic.do Mariano Garcia, párroco». Nuevas adquisiciones de partituras musicales van firmadas y datadas en Calatayud el 18.01.1893, fecha en la que los miembros de la Capilla de Música (Enrique Comes, Miguel Lezaún Jacinto García José M Pardos, y Mariano Clemente) establecieron unas interesantes capitulaciones al respecto. 
dier, Bonifacio Iráizoz, Luis Iruarrízaga Aguirre, T. Istúriz, D.J.P., V. J., Fray Estanislao de Jesús, Maria Lucila de Jesús, Maria Raquel de Jesús, d.l.b. Manuel Laguía, Florencio Lahoz, Antonio Lomarca, Juan Bautista Lambert y Caminal, Serafin Larroca, Nicolás Ledeshoz, Antonio Lamarca, Juan Bautista Lambert y Caminal, Serafin Larroca, Nicalás Ledesma García, Miguel Lezaún, J. Librada S., Antonio Félix Lozano González, Ignacio Llauradó, M., R. M. N., Juan Bautista Marabini, Martin Pierre Joseph Marsick, José Angel Martinchique, Manuel Martinez Posse, Domingo Mas y Serracant, Estanislao Mateu, Tito Mattei, Giuseppe Saverio Raffaele Mercadante, Antonio Mercé y Fondevila, Medo, VaJó Maria Namino, Mariano Nauarro, Manuel Neira, Igmacio Nogueras Valerdi María del $C$. (Mon Nogueras, M. Nou, Eederico Olmeda de San Jos, Ma Orihuela, Miguel Antonino Osanz, Rlemigio Ozcoz y] Calahorn, Ozi, I. P., M.P., R. P. Giovanni Pacini, Miguel Palacín y Cabrero, Palancar, José Perpinán, Giovanni Pierluigi da Palestrina, Ildefonso Pardos Arrúe, Ildefonso Pardos Lezaún, José $M^{a}$ Pardos Lezaún, Roque Perales, J. Pérez de Ciriza, Juan Ginés Pérez, Mariano Pérez, Perard, Lorenzo Perosi, Émile Louis Fortuné Pessard, José Perpiñán, Luis de Pla, Ignaz Joseph Pleyel, J. B. Po Uleri, Ponti José Ramón de Prado, José Preciado, Joseph Joachim Raff, Alberto Randegger

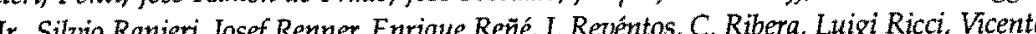
rin ,

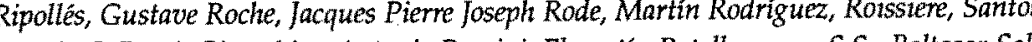
Rosado, J. Rossi, Gioacchino Antonio Rossini, Florentin Rotellar, m.S., S.S., Baltasar Saldoni, Justo de San José, Fray José Antonio de San Sebastián [Padre Donostia], Sanclemente, Juan Angel Sánchez, José Sancho Marraco, Sanclemente, C. Santamarina, Fray Emeterio de Santa Teresa, José Juan Santesteban, Mariano Nemesio Santos Iranzu, Manuel Sanz, Franz Schubert, Giovanni Serpentini, Manuel Serrano, Sierra, Johannes Silesius, B. Simo, B. Singelée, José Sobejano y Ayala, Manuel Soler Palmer, Indalecio Soriano Fuertes, Jos Soriano, L Sorribes, Daniel Stribelt Johann Strauss, Jozsef Szigeti, Érile Tavan'thl Telle-

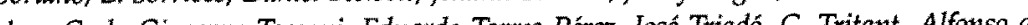
chea, Carto Giuseppe Tesqu, Eduardo Torres Perez, Jose Thado, G. Thitant, Alfonso de Ugarte, Luis Urteaga, José Maria Usandizaga, P. V., Julio Valdes Goicoechea, A. Valenti, V. Valenti, José $M^{a}$ Varela Silvari, Vargas, Luis Velasco, Giuseppe Verdi, Fernando Verdú, Ludovico Viadana, A. Vicens, Antonio Vidaurreta, Henri Vieuxtemps, Julián Vilaseca, Enrique Villalba, M. Villalba, Luis Villalba, Elias Villarreal, Paul Wachs, Henryk Wieniawski, P. Zarranz, y Nicola Antonio Zingarelli.

Las partituras acumuladas, que no cesaban de aumentar con el paso de tiempo, dieron lugar a una creciente preocupación en los músicos, que llegaron a establecer unas capitulaciones al respecto en 1893 , con vistas a determinar a quién y en qué modo correspondían los derechos sobre las mismas y la propiedad de esos fondos ${ }^{45}$.

45 "Los que suscriben componentes la Capilla musica de la Yglesia del Santo Sepulcro de esta 45 "Los que suscriben componentes la Capilla musica de la Yglesia del Santo Sepulcro de esta
Ciudad, con motivo de poseer varias obras musicales tanto del genero Religioso como profanas, adquiridas de su propio peculio y los que en lo sucesivo puedan adquirir, tienen acordado formalizar las condiciones por las que se facilite la transmisión de derecho en la parte que á ellas pueda corresponderles á aquel ó aquellos que sustituyan á uno ó mas individuos de los que hoy constituyen la referida Capilla musica. $1^{*} \ldots$ Los valores de las referidas obras compradas (las cuales aparecen en el inventario unido á este documento) hasta la fecha como igualmente los gastos de papel para copias de aquellas que se faciliten con este obgeto, y demas accesorios. Quieren: Que el individuo que sustitu-
Como comentario al repertorio conservado y los autores reflejados en el archivo, conviene señalar que -como sucede en otros muchos archivos eclesiás-

ya á aquel que falleciere, trasladase su residencia á otra poblacion, se despidiere de la Capilla ó dejase de pertenecer á ella por causas agenas á su voluntad, se le abone por el referido sustituto en el cargo, la cantidad que le corresponda del valor de las referidas obras compradas, papel, copias y demas gastos; y en defecto del finado, á su viuda, hijos legítimos de aquel 6 á sus habientes derecho, y caso de que no los hubiere, recaera en el fondo destinado al obgeto principal de este documento, la suma que le correspondiere recibir. $2^{2} \ldots$... Por el sustituto 6 quien reemplazare á aquel que dejare de pertenecer á dicha Capilla por los motivos espresados en la anterior condicion, se hará entrega de la cantidad que le corresponía por los conceptos consignados en la referida condicion en el ternino de seis meses á contar desde el momento en que se vea á lo que le corresponde abonar, y en el caso de que por no haber funciones durante ese tiempo ó no le permitieran sus faculades pecuniarias desprenderse de cantidad alguna para cumplir con po $\delta$ no le perniteran sus facultades pecuniarias desprenderse de cantidad alguna para cumplir con aquella condicion, se examinarán los fondos si hubiere y en tal caso se le hará entrega al saliente de lo que lo

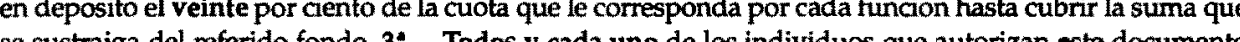
cescento se obllgan condicich a sica rello lo hublerc) la la Iglesia 6 el Capitulo de la nisna aurentaran el numero de los que hoy constituyen la espresada Capilla musica, en este caso, for pradas hasta aquella fecha y demas accesorios y del dinero (si hublere en fondo) se verficara un reparto entre todos y lo que correspondiera a los nuevos entrantes lo abonaran en la forma que se deja consignado en la condicion segunda. 5 ... Si hubiere alguno que se negase á hacer el reembolso de la parte que le corresponda por el valor de las obras en la forma que queda espresado en la condicion segunda, no tendrá derecho a ellas y por consiguiente a que se le abone el dia que dege de pertenecer la suma que le correspondiera; en este caso se marcara un tanto á cada una de las obras, para que cada vez que se haga uso de ellas se le descuente de lo que le correspondiere á aquel individuo, es decir que el dia que se cante la misa del Maestro Eslava se mira lo que ha costado y repartido entre los que compongan la Capilla lo que á él le toque se le ha de descontar y lo que resultare quedará en fondo. $6^{\circ} \ldots \mathrm{Si}$ un individuo de los que hoy componen la Capilla o los que en lo subcesivo pudieran componerla se negase á asistir á las funciones particulares produciendo con esto un perjuicio á los intereses de la misma, no tendrá opcion ni él ni sus habientes derecho á la parte que pudiera reclamar del valor de las obras compradas y mucho menos del fondo (si lo hubiere) dedicado á aquel obgeto. $7^{\mathrm{a}}$... El encargado de la Capilla y por lo tanto depositario de las obras propiedad de la misma no podra facilitar ninguna de ellas al que las pidiere, sin permiso mutuo de todos los individuos que componen dicha Capilla; como asi mismo el instrumentocontrabajo, tambien propiedad de la sobre dicha Capilla, por ningun concepto se pernitirá hacer uso de él, si no es en actos en que asista el numero completo de la misma, á no ser que un caso escepcional en que con mutua anuencia de todos se acordase facilitarlo á uno de los cinco individuos que constituyen aquella y para ello se hace preciso que aquel que lo solicite posea ó toque aquel instrumento. $8^{4} \ldots$ Con obgeto de que no se dude de la inversion de fondos (cuando los hubiere), los cuales resultaran en su caso de lo que se deposite del valor de cada funcion y para que no pueda sospecharse de la legalidad del encargado, habra un interventor que sera nombrado de entre los que hoy la componen, que llevara anotacion en la que aparezca el valor de las obras que se compren, el de las que se copien, papel y demas accesorios y por ultimo las cantidades que para este obgeto se descuenten del valor de las funciones. Queremos que las presentes condiciones sean respetadas y se respeten por cuantos fueren nuestros sucesores; sin perjuicio de que si con el tiempo tanto los firmantes como los que en lo subcesivo pudieran remplazarnos, si alguna de las anteriores condiciones creyeren ser conveniente el reformarlas en beneficio de la asociacion musical puedan hacerlo con conocimiento de todos ${ }^{\prime \prime}$ 
ticos españoles de características similares a éste- se observa una importante producción de maestros principal aunque no exclusivamente locales (Lázaro Gaínza, Rafael Guasch, Manuel Laguía, Miguel Palacín, Ildefonso Pardos, Roque Perales, Flonentino Rotellar, Ângel Sánchez, Mariano Santos, Vargas...), otros con una mayor proyección nacional (R. Carnicer, R. Cuéllar, José Ángel Martinchique, Nicolás Ledesma, H. Eslava, Pablo Hernández, Plá...), y también extranjeros (Allegri, Amatucci, Asioli, Battmann, Boissière, Bordesse, Bottazzo, Perosi, Rossi), entre los últimos de los cuales cobran especial interés las obras de carácter instrumental de Concone, Haydn, Ozi, Pleyel, Steibelt, Toeschi...

Precisamente, entre la mejor música que se conserva, se cuentan numerosos ejemplos de obras de los compositores franceses e italianos más destacados de los siglos XVIII y XIX, entre ellos, de operistas como Rossini, Bellini, Donizetti, Mercadante, Pacini, Ricci, Gounod, Meyerbeer..., por lo general, autores todos ellos cuyas obras están bien repartidas por los archivos españoles; pero, junto a ellas, también hallamos, rasgo característico de este archivo, obras a priori más alejadas de la tradición eclesiástica hispana, procedentes de círculos civiles parisinos y aun del área germánica: los cuartetos de cuerda de Daniel Steibelt, oberturas de Carlo Giuseppe Toeschi, antiguas piezas manuscritas para piano de Ignaz Joseph Pleyel, o excelentes impresos franceses de algunos de los más célebres conciertos para fagot de Etienne Ozi

Asimismo, cabría destacar la importancia porcentual que cobra la música "devocional" (gozos, letrillas, rosarios, jaculatorias, despedidas a la Virgen, flores de Mayo, cánticos al Sagrado Corazón...), así como, como ya va dicho, la de aquella música que podríamos considerar como más alejada de lo estrictamente litúrgico (óperas, zarzuelas, cavatinas, duetos de obras dramáticas, piezas de salón del tipo polcas, valses, rigodones, mazurcas, minués...).

Por último, es preciso reivindicar aquí la figura del compositor Mariano Santos, verdadero "motor" de la capilla musical del Santo Sepulcro en el siglo XIX, por cuanto, además de su copiosísima producción musical (sus composiciones son, con diferencia, las más abundantes del archivo), realizó una prolí fica y colosal tarea de copia de otras composiciones, además de numerosas transcripciones, arreglos, orquestaciones de obras de otros autores, etc. etc.

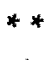

\section{HISTORIA MUSICAL DE LA COLEGIAL DEL SANTO SEPULCRO:}

A falta de series completas o continuas de documentación auxiliar (libros de actas, de fábrica, pagos, etc.), los datos con que contamos hasta el momen- to para reconstruir la historia de la capilla de música de la colegial bilbilitana del Santo Sepulcro, son dispersos en su temática, y en el tiempo. Buena parte de ellos, procede de volúmenes del tipo "quinque libris", por lo que la concreción acerca de los músicos de nuestro interés se reduce a sus fechas de nacimiento o muerte. Exponemos a continuación el material al respecto que hemos podido recoger, ordenado cronológicamente:

Hacia finales del siglo XVI, - varios años antes de la construcción del nuevo templo ya en el siglo XVII-, sabemos que esta colegial contaba con capilla de música propia (al menos desde el año 1591), pues entre los «confesados y comulgados» de ese año en la parroquia bilbilitana del Santo Sepulcro, constan documentalmente varios músicos, citados como «los de casa»: Pedro Ximeno, tañedor del órgano; mosén Bernal, contralto; Pedro Cavero, contrabajo; y Pedro Martín, tiple. Al año siguiente, desaparece de la lista mosén Bernal, y se añaden al resto, los infantes Pedro Cebolla, y Gaudiosico.

Según actas capitulares de Santa María, el viernes 29.05.1592 "propuso el Señor Deán [de aquella iglesia] que era necesario dar alguna cosa a los menestriles. Resumió el cabildo se les diese 16 reales, y seis a un capón del Sepulcro", como pago extraordinario por su actuación musical. En 1593 se cita de nuevo en la documentación del Santo Sepulcro a Pedro Ximeno y Pedro Cebolla (hasta 1594), y aparecen, nuevos, el tiple Agustín, y el contralto Jerónimo Villafranca (hasta 1612)

En 1595 la capilla musical aumenta considerablemente: Pedro Ximeno, maestro; Villafranca, contralto; Pinilla, tenor (sigue en 1599); Domingo Blasco, contrabajo (sigue en 1599); Domingo Fojos, tiple; Miguelico y Juanico, infantes.

Poco a poco, se observa una capilla musical que consta ya de maestro y organista (Pedro Ximeno sigue apareciendo citado hasta $1606^{46}$-en ese último año aparece como "cantor"-), además de tiple, contralto, tenor y contrabajo, dos infantes —en 1599 se distingue entre ellos un "infante mayor», que en 1601 era un tal Rodicas-, y músicos de ministril, como corneta, bajón, etc.

A comienzos del siglo XVII, - 1602-, consta por los "quinque libris" de la colegial que era infante mayor Juan «el Rullo» ${ }^{47}$. En 1612, entre otros,

${ }^{46}$ Consta que este maestro de capilla y organista disponía de "criada" en el año 1599: entre "Los conductos de casa", aparece "Po. Ximeno y su criada" (Vid.: "Cinco libros / de la Parroquia del / Santo Sepulcro / de Calatayud / $1^{\circ}$ / Bautoz. 1579-hasta 1734". [Fol. 224v.] [Encabezamiento]] «Memoria de los confessados y comulgados en la Parrochial del Sepulcro en el año de 1599"). Este libro se trata de un volumen manuscrito con hojas de papel, encuadernado en pergamino: [Lomo:] «Cinco libros / Sto. Sepulcro». [Etiqueta pegada en el lomo:] "Cinco Libros / Sto. Sepulcro / $1^{\circ}$ Tomom. [Portadilla:] «Cinco Libros / de la Parroquia de la Insig.e / Colegial / Real y Regular Yglesia del / Santo Sepulcro Hyerosolimi ${ }^{\circ}$. / de / Calatayud / Empiezan en el Año 1579».

${ }_{47}$ Véase: [Tapa:] «Cinco libros / de la Parroquia del / Santo Sepulcro / de Calatayud / $1^{\circ} /$ Bautoz. 1579-hasta 1734*. Siendo Juan el Rullo infante mayor, apadrinó el 0401.1602 el bautizo de Catalina Gil Carcía. 
constan como miembros de la capilla musical Pedro Sánchez, y el infante Pedro Aguilar.

Una vez levantado el nuevo templo bilbilitano del Santo Sepulcro, sabemos que en 1632 era organista de la Catedral de Teruel el músico Juan de Rue$\mathrm{da}$, turolense, quien probablemente había sido poco tiempo antes organista en la Colegiata del Santo Sepulcro de Calatayud. Por su parte, el tiple del Sepulcro Pedro Morte, fallecía y recibía sepultura en la iglesia en 1633; y ese mismo año se documenta también a los cantores Clemente Nuño (que lo fue al menos hasta 1636) ${ }^{48}$, y Jaime Sanz (hasta 1635).

Por las listas de confesados y comulgados en la parroquia, sabemos que en el anteriormente citado año 1633 era el organista de la iglesia Miguel Asturiaque (hasta 1635). $Y$ también desde 1633 , hasta, al menos, 1645 , actuaba como bajonista Francisco Lorente ${ }^{49}$. En 1635 podemos añadir al elenco de músicos nuevos nombres - la mayor parte, seglares y casados-: Mateo Gascón, cantor; Francisco Gisarol, cantor y corneta; Gaspar Bux, cantor; Sebastián Hernández, tiple; mosén Jacinto Martínez, contralto; o mosén Agustín Sesé ${ }^{50}$, corneta - hasta 1636-

48 Marchó a Sigüenza en Mayo del año 1635, llamado por el cabildo de aquella catedral, para dar muestra de su voz de "contrabajo", por lo que fue recompensado con 150 reales de ayuda de costa poco más adelante, fue definitivamente reclamado desde dicha ciudad, pues se le halló a propósito para el cargo, que cubrió con 2000 reales de salario. (Vid.: SUÁREZ, Javier: La mísica en la catedral de Sigüenza, 1600-1750. 2 vols., Madrid, ICCMU, col. «Música Hispana. Textos», 1998, pp.98 y 100-101).

${ }^{49}$ Hizo elección de parroquia en el Sepulcro, constando documentalmente junto a su esposa como "cónyuges forasteros"; con ocasión del bautizo de un hijo suyo en 1634, fue su padrino el también músico mosén Agustin Sesé. Entre 1639 y 1641, el bajonista Francisco Lorente "y su muger y los de su casa" - tuvo varias criadas-, aparecen citados, con entrada diferenciada - lo que sin duda realza su importancia-, entre los miembros de la capilla musical del Santo Sepulcro.

${ }^{50}$ Mosén Agustín Sesé (*Cantavieja - Teruel-; Mendavia - Navarra-, 1654). Los músicos apellidados Sesé (o «Sessé») conformaron una familia de notables instrumentistas, músicos de ministril -y alguno de ellos, organista-, localizados fundamentalmente en Huesca y Pamplona. Que sepamos, hasta la fecha no se les había relacionado con la ciudad de Calatayud. En todo caso, se sabe que ya durante el magisterio de capilla en la Catedral de Huesca de Mateo Calvete, se dio un beneficio (24.11.1620) al presbítero Agustín de Sesé, que actuó ahí como "superintendente de la copla de los menestriles", además de ministril tiple, corneta director, bajonista y sacabuche, y responsable de un juego de nueve flautas traidas desde Inglaterra. En 1631, por problemas entre los musicos, el cabildo oscense despidió a todos los ministriles, y sólo más tarde fueron readmitidos algunos (el último, mosén Sesé). Acaso, entretanto, pasara Agustín Sesé al Santo Sepulcro de Calatayud, aunque, caso curioso en 1638, el cabildo oscense le perpetuaba el beneficio nutual, citándole de nuevo como superintendente de la copla de ministriles; por su parte, Sesé se comprometía en Huesca a tocar durante toda su vida en la catedral la "corneta y ministril" y a enseñar a un sobrino suyo, Jusepe Sesé, para que pudiera suplirle. En 1643 se mandaba ya buscar en Huesca un capiscol corneta, de donde se deduce que Sesé habria partido ya. [Para las informaciones anteriores, véase: EZQUERRO, Antonio: La Música vocal en Aragón en el segundo tercio del siglo XVII: tipologías, técrnicas de composición, estilo y relaciôn músicatexto en las composiciones de las catedrales de Zaragoza, Tesis doctoral en microforma (4 microfichas). Barcelona, Universitat Autònoma de Barcelona, Facultat de Filosofia i Lletres, Publicacions de la UAB,
Por aquellas fechas debió ejercer el magisterio musical de la iglesia Juan Ramos, a quien ya vimos reflejado con unas lamentaciones de su composición copiadas en los cantorales de la iglesia, y que murió el 23.08.163951

En 1643 era maestro de capilla de la iglesia del Santo Sepulcro el célebre compositor Urbán de Vargas ("Falces -Navarra-, 1606; +Valencia, 1656), que, procedente del vecino magisterio de capilla de Santa María, en la misma ciudad, aparece aquí casado con Luisa de Amezqueta y Zabalza, y que tuvo ese año un hijo llamado Manuel, bautizado en la iglesia jerosolimitana de Calatayud el 17.01.1643. Probablemente, aunque no hay constancia ni certeza alguna sobre este punto, poco después, Vargas enviudaría, de modo que en 1645 accede al magisterio de capilla de El Pilar de Zaragoza siendo ya sacerdote. Este maestro, uno de los más destacados del ámbito eclesiástico hispano durante el período barroco, llegó a ocupar los magisterios de las catedrales de Huesca, Pamplona, Burgos -como canónigo-, El Pilar de Zaragoza y la metropolitana de Valencia.

Entretanto, en la iglesia del Santo Sepulcro los músicos seguían sucediéndose sin prisa pero sin pausa. En 1644 llegaba como nuevo bajonista Adrián López, asimismo casado (hizo elección de parroquia en el Santo Sepulcro el

Microfitxes: Micropublicacions ETD S.A., 1997 [cfr. especialmente el volumen 5, de «Anexos»; los datos de la presencia de los Sesé en Huesca, así como otros varios, pueden verse en: DURÁN GUDIOL, Antonio: "Los manuscritos de la catedral de Huesca". En: Argensola, IV, 1953; Ibid.: "Los maestros de capilla de la catedral de Huesca", ibid., X, 1959; loid: "Organos, organeros y organistas de la catedral de Huesca, ibid., X, 1959; Ibid.: "La capilla de música de la catedral de Huesca.. En: Anuario Musical, XIX, 1964 (1965)]. Por su parte, en la capital navarra hallamos como "capellán músico de corneta" de su catedral, nombrado el 20.06.1638 a un tal mosén Jeromin Sessé. Ahí mismo, el cabildo pamplonés, con la intención de evitar el empleo de la guilara en dester. Ahs qu. que asta agora se an cantado muy viejo y por faltarle mucho de la vista no es de provecho. Tras este, aparecerá en la seo pamplo17. 12.1659, y +1691] presbitero [se Zaso desde 17.12.1659, y +1691], presbitero de Zaragoza, músico de corneta, que fue nombrado en 1655 por muerte de Agust Sesse, sin duda el mismo músico al que hallamos en la colegiata del Santo Sepulcro de Calatayud, y del que desconocemos en que momento habria accedido a la seo pamplonica. [Datos procedentes de Pamplona, tomados de. HERNANDZ ASCUNCE, Leocadio: "Musica y músicos de la Catedral de Pamplona". En: Anuario Musical, XXII (1967). Barcelona, 1969, "pp.226-227; la información más amplia sobre la familia Sesé en Navarra, en: ZUDAIRE, Claudio: "El músico aragonés Agustín de Sese +1654 . Su testamento. Y otros musicos Sese de la Catedral de Pamplona". En: Nassarre, II/2, 1986, pp.187-196; ahi, entre otros datos, se anota lo siguiente: Domingo Sesé: músico residente en Santo Domingo de la Calzada, pasó luego a Pamplona, donde falleció antes de 1661. Casado con Catalina Sánchez de Vergara. Padre del también músico, el presbítero Francisco de Sesé, bajonista de la seo pamplonesa, y del hermano de este último, Andrés de Sesé, que fue organista de San Nicolás de Pamplona y luego de San Lorenzo en la misma capital navarra].

51 "Cinco libros de la Parroquia...*, op. cit. [Fol. 126r:] [Margen:] «1639»: "En 23 de Agosto de 1639 murio el maestro Ramos maestro de capilla del Santo Sepulcro enterrose en el Sepulcro. hiço testamento el regente de la vicaria cumplieronse con el testamento". 
07.05.1644). En 1645 accedió al magisterio de capilla del Santo Sepulcro de Calatayud el interesante compositor Miguel Juan Marqués (fl.1641-1661), que se había formado en esa misma iglesia como discípulo de su predecesor en el magisterio, el maestro Urbán de Vargas. Marqués accedía al magisterio jerosolimitano de Calatayud desde el de la Colegiata de Daroca, por la que también antes pasara su profesor, quien parece que le fuera promocionando sucesivamente en los puestos que él abandonaba (más tarde, en El Pilar de Zaragoza) De este maestro Marqués, que ocupara el magisterio bilbilitano hasta, al menos, Mayo de 1648, sabemos que tenía un hermano menor, llamado Pedro, también músico, que había actuado con anterioridad en su capilla darocense como infante tiple y que pasó luego como cantor a Zaragoza. Ocupó también las maestrías musicales de Daroca (1642-1645), la Catedral de Teruel (que acaso no llegara a desempeñar), y El Pilar de Zaragoza (1653/6-1661) ${ }^{52}$.

En el año 1658 algo extraño debió suceder, pues consta que el músico Diego de Bados se casó con Catalina Yepes de la Peñaa ${ }^{53}$, aunque casi dos meses después de haber bautizado, en la misma iglesia del Santo Sepulcro, a un hijo de ambos, al que, por cierto, apadrinó Matías Mira, acaso ya para entonces maestro de capilla de la colegiata; tal vez se tratara simplemente de una cuestión de formalidad en el registro o certificación de un matrimonio efectuado con anterioridad en otra iglesia, es decir, de un papeleo pendiente de llegar

${ }^{52}$ Sobre estos compositores (Vargas, Marqués), véanse: EZQUERRO, Antonio: La Música vocal en Aragón en el segundo tercio del siglo XVII..., Op.cit.; cfr. especialmente el volumen 5, de "Anexos». Ibid. ed.: Antonio Lozano González: La Música Popular, Religiosa y Dramática en Zaragoza desde el siglo XVI hasta nuestros dias (Zaragoza, 1895). $3^{\text {a }}$ edición corregida y aumentada [con adición de aparato gráfico, in troducción, estudio, epistolario de Felipe Pedrell, e índices]. Zaragoza, Gobierno de Aragón-Diputación de Zaragoza-Ayuntamiento de Zaragoza, 1994. Ibid.: Villancicos aragoneses del siglo XVII, de una ocho voces. Barcelona, Consejo Superior de Investigaciones Cientificas, «Monumentos de la Música Es pañola, LV", 1998. Ibid.: "Vargas, Urbán de" y "Marqués, Miguel Juan", en Diccionario de la Música E pañola e Hispanoamericana. Madrid, SGAE, en prensa.

${ }^{53}$ Citamos las partidas correspondientes, todas ellas anotadas en los "quinque libris" de la iglesia («Cinco libros de la Parroquia...», op. cit.), por orden cronológico [s.e.u.o.]: [Fol. 19r.:] [Margen:] «Año 1658m. "Baptiçe yo Moss. Juan de Langa regente la cura del S.to Sepulcro de Calataiud en 18 de març de 1658 a Diego Hijo de Diego de bados musico y Catalina yepes de la Peña Padrinos Matias Mira Catalina Gonçalo". [Fol. 166r.:] [ $\times$ Los q. se an casado desde el año de 1578 en adelante son los siguientes"] [Fol. 174r.:] [Margen:] «Diego de Bados y Catalina la Peña»: "En diez de mayo de 1658 oyeron misa nupcial en la iglesia del S.to Sepulcro Diego de Bados musico de esta iglesia i Catalina de la Peña hauiendo precedido todo lo dispuesto por el S.to Concilio como largamente me consto assi el infra escrito Vicario, por relacion del cura de la Ciudad de Siguença, i por testimonio de dos notarios publcos i apostolicos, i por ser verdad lo firme dicho dia mes y año. Moss. Juan de Langa". El matrimonio todavía tuvo otro hijo, bautizado años después en la iglesia del Santo Sepulcro: [Fol. 19v.:] [Margen] "Jacinto Bados». "En 19 de Agosto de 1661 Bautize yo Moss. Juan Antonio Ruster a Jacinto de Bado hijo de diego de bados y Maria la peña Coniujes fueron Padrinos Joseph Conches y Catalina Ximeno [Por su parte, en el mejor trabajo disponible sobre la música en Sigüenza, no aparece citado ningú músico apellidado «(de) Bados»; vid.: SUÁREZ, Javier: La música en la catedral de Sigüenza..., Op. cit.]. desde Sigüenza, de donde procedía la pareja [?]. En 1659 eligió la parroquia del Sepulcro «Valero Vergara, Músico», que fallecería el 09.03.1675, siendo citado entonces como "bajonista y arpista de la iglesia del Santo Sepulcro"; y "se dejo para su entierro y missas beinte escudos". Entretanto, en 1660 había muerto el corneta Martín Navarro. Y en 1665 murió mosén Juan Martínez, "ministro por músico de esta iglesia».

Nuestra siguiente noticia data de 1666 , cuando actuaba ya como maestro (acaso lo hiciera desde tiempo atrás - 1663 ó 1664-) Matías Mira, quien iba a ejercer el magisterio de capilla de la iglesia del Santo Sepulcro de Calatayud hasta su muerte, ocurrida el 17.06.1684, cuando, gracias a los bienes que dejó, se pudo instaurar "la fundacion de un aniversario perpetuo en la Yglesia"54. De los años de magisterio de Matías Mira, contamos con varios nombres de los miembros que pasaron por la capilla musical que él dirigía. Entre otros ${ }^{55}$, destaca el organista, Francisco Martínez, que, fallecido el 30.11.1677, "dexo para su alma cinquenta escudos", o el corneta mosén José $\mathrm{Núñez}^{56}$. Precisamente, el año del óbito del maestro Mira, fallecieron también otros varios miembros de su capilla ${ }^{57}$.

Durante el magisterio de Matías Mira se produjeron algunos datos de interés musical: en 1675 sabemos que se juzgó positivamente en la cercana $\mathrm{Ca}$ tedral de Sigüenza al tenor del Santo Sepulcro (posiblemente el mismo barítono o contrabajo citado poco antes en la documentación seguntina) mosén

${ }^{54}$ Sobre Matías Mira sabemos que cumplió con su parroquia anualmente —es decir, que se confesó y comulgó, como así consta entre 1666-1677-

${ }_{55}$ En 1666: su hermano, Pedro Mira (se le cita, sin explicitar cargo musical alguno, hasta el año 1675); Joseph Mora; Martín Luis; y Domingo Montes, e Iturbide, infantes de coro. En 1667: Diego Calbete (probablemente infante, aunque tal vez cantor de capilla, que registra su nombre en uno de los ejemplares del pasionario de Lanaja y Quartanet); y Domingo Joaquin Morón, infante, voz de tiple, que consta cantó el Passio el 31.03.1667. (Este mismo, recibió, de manos de un tal Pedro Zabala, $60 £$ "por suma de más cantidad quel dicho me debe pagar"). El 12.04.1669 cantaba el Passio el tiple Miguel Calixto Iranzo. En 1673: se cita como miembros de la capilla de música a Andrés Iturbide (hasta 1675); y mosén Juan Iturbide (hasta 1675). En 1674-1676: Juan Francisco Pintor, infante. En 1678 actuaba como cantor de la iglesia el cantor Felipe Duarte, que consta entonces como testigo de un matrimonio celebrado en el Santo Sepulcro bilbilitano.

${ }^{56}$ De este último, por aquel entonces "de conocida habilidad y mozo de buena salud", se pidieron informes en 1683 desde la Catedral de Sigüenza —donde constaba además como "sujeto muy científico y de toda habilidad y buena elección" - al maestro de capilla del Santo Sepulcro bilbilitano, Matías (de) Mira, y al maestro de la colegial de Santa María, Manuel Casajús. Tras el parecer favoraMatias (de) Mira, y al maestro de la colegial de Santa Maria, Manuel Casajús. Tras el parecer favorable de ambos, se supo en Sigüenza que Núñez sabía tañer corneta, chirimía, bajoncillo y arpa de dos ordenes, además de "entender de composición, que pocas veces se halla en ministriles", lo que da cuent del alto nivel profesional de los músicos de la capilla del Sepulcro. Se recibió en Sigüenza en za... Op. cit. pp. 209-210 y 215).

${ }_{57}$ Es el caso del tenor Manuel

. dro Zorraquino (citado «Corrachino»), fallecido el 30.12.1684, a los 12 años de edad. 
Gracián Berdeque ${ }^{58}$; entre 1675 y 1678 hallamos en la iglesia del Santo Sepulcro algunos documentos que muy probablemente puedan hilvanarse con la presencia en Calatayud de la amplia familia de músicos apellidados Navas, que alcanzaran gran fama como compositores de música escénica (zarzuelas, comedias para las fiestas reales...) en la corte madrileña de Felipe IV, Carlos II y Felipe V. Entre otros, sabemos de la presencia en Calatayud de Juan Gómez de Navas (maestro de Santa María) y de su hijo, Juan Francisco Gómez de Navas, nacido en la capital del Jalón y años más tarde, el músico más prestigioso de la saga familiar, arpista y compositor a un tiempo, que aprobó con su parecer diversos tratados teóricos de composición y puso en música algunas de las composiciones más celebradas por la monarquía hispánica ${ }^{59}$.

En este sentido, hemos hallado últimamente entre la documentación de la iglesia del Sepulcro de Calatayud a un "Juan Gómez ${ }^{60}$ que aparece como casado y padre de tres hijos bautizados años más tarde en esta iglesia bilbilita$\mathrm{na}^{61}$. De forma similar, encontramos algunos datos relacionados con la música alusivos al apellido Almazán: en 1680 muere intestado el licenciado Antonio Almazán, de modo que el vicario de la colegial entregó su cadáver a los religiosos de la Merced, a la puerta de aquella iglesia, "con la música de Sepulcro", es decir, con presencia de la capilla musical de la colegiata. Y dos

${ }^{58}$ Vid.: SUÁREZ, Javier: La música en la catedral de Sigüenza..., Op. cit., pp. 187-188.

${ }^{99}$ Véase la citada tesis doctoral: EZQUERRO, Antonio: La música vocal en Aragón.... Op.cit., vol. 5 "Anexos", apartado [l "Compositores" «[XV] Juan Gómez de Navas», pp. 167-184.

${ }^{60}$ Según su partida de matrimonio, siendo mancebo, se casó, «por palabras, de presente", el 111.1675 con Catalina Sanz doncella "abiendo procedido las tres moniciones que el Santo Concilio

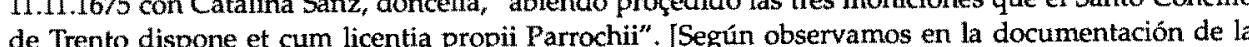
de Trento dispone et cum licentia propin Parrochir. [Segun obseram iglesia, en el año 1679, fallecido el, su viuda vuelve a casarse en segundas nupcias]. Lo hijos que tuvo el matrimonio se registran asi en sus partidas de bautismo: - $[$ Quinque libris de la Colegiata del Sant Sepulcro de Calatayud, Bautizados, fol.23r.:] [Margen:] «Theresa Rosa Gomez”. "En diez y siete de octubre de mil seiscientos setenta y cinco con licencia de Mossen martin Lozano Regente Bautizo Mossen Juan Bautista sachristan a teresa Rosa Gomez ija de Juan Gomez i de Catalina Sanz conjuges fue ron padrinos Mossen Joseph Balsa y Esperanza Martinez. Mossen Martin Lozano Regente". [Fue confirmada el 26.08.1676 en la parroquial de San Miguel de Calatayud por el obispo de Tarazona D. Antonio Francés de Urrutigoiti]. -[Ibid., fol. 23v.:] «Año 1677». [Margen:] "Blas Pasqual". "En beinte y nuebe de henero de mil seiscientos setenta y siete bautiçe a Blas Gomez ijo de Juan Gomez y de Catalina Sanz coniuges fueron padrinos Blas Pasqual y Margarita Cortes y por la verdad hiçe la presente relacion en 29 de henero de 1677. Mossen Martin Lozano Regente". •[Ibid., fol. 25r:.] [Margen:] «Catalina Andres Gomez". "En un dia digo en el primer dia del mes de deciembre del año mil seiscientos setenta y ocho yo el Abajo firmado baptize a Catalina Andres Gomez ija de Juan Gomez i de Catalin Alcalde conyuges fueron padrinos Pedro Gomez y Esperança Martinez i para la verdad hiçe la presente relacion en Calatayud a uno de deciembre de 1678. Mossen Martin Lozano".

${ }^{a}$ La información anterior complementa y completa la ofrecida con anterioridad en: EZQUERRO, Antonio: La Música vocal en Aragón..., Op. cit.; cfr. especialmente el volumen 5, de "Anexos», así como en Ibid:: "(Gómez de) Navas, Juan de". En: Diccionario de la Música Española e Hispanoamericana. Madrid, SGAE, en prensa. años después fallecía Jusepe Almazán, asimismo pobre e intestado, por lo que se enterró de limosna en el citado convento de la Merced, "con los ministros del Santo Sepulcro".

Por otro lado, muerto ya el maestro Mira, en los años 1686 y 1687 consta que era contralto de la colegial, y que cantó el Passio, Miguel de Lizaga. Aquel mismo año de 1686 aparece en la iglesia como músico, sin especificar su especialidad, "Don Andrés García".

Un tiempo después, obtenemos alguna noticia a partir del Libro para la $\mathrm{Ca}$ xa que empieza en 15 de Junio de 1690 (incluye los años 1689 al 1695, ambos inclusive), que se conservaba no hace muchos años en esta colegiata, y que ahora se encuentra en el fondo documental depositado en el Archivo Histórico Diocesano de Tarazona. En este volumen, se documentan pagos, en los años 1690 y 1691, por su salario, "a D.n Bruno Falqués y otros Ministriles", y "lo mismo por el salario de $1692^{\prime \prime}$. A partir de 1692, sin citar nombres, se paga asimismo "a los Ministriles del Reino", lo que se repite anualmente hasta 1696.

Mientras tanto, a primeros de 1691 había fallecido mosén Joseph Núñez, corneta en La Seo de Zaragoza, que en su testamento dispuso la mayor parte de su hacienda para la iglesia del Santo Sepulcro calatayubí, con vistas a fundar una capellanía en la capilla de San José y, si no alcanzara, para cargar aniversarios y misas hasta donde hubiera posible.

Ya en 1697, certificamos que era maestro de capilla de la colegial del Sepulcro mosén Domingo Ximénez (consta como maestro, al menos, hasta 1699, fecha en que aparece citado como tal, en el acta de bautismo de una niña, a la que apadrinó); su hermano, Francisco Ximénez, actuaba como tiple en la misma colegial, y ese mismo año de 1697 se registra que cantó el Passio.

Otros cantores de la Pasión en esta iglesia durante el siglo XVII, aunque desconozcamos sus fechas concretas de actuación, habrian sido, a juzgar por sus propias anotaciones en el juego de tres ejemplares del pasionario impreso en 1612 por Lanaja y Quartanet, los siguientes: «Fermin Ciria, Juan, Pedro Benedito y Cortés, Lorenzo, Rios, Florencio Blasco, Fran[...], $\mathrm{M}^{\circ}$, Miguel Meçiado [?], y Juan Vargas» ${ }^{62}$.

Alcanzado ya el siglo XVIII, el 02.08.1701 se registra en la iglesia del Sepulcro el matrimonio de Francisco Joaquín Luna y Mañero, del obispado de Palencia, con Josefa Sesma, de Tudela, ambos «farsantes», y «de presente en dha Ciudad de Calatayud y representando en la Compañia de Joseph Antonio de Errada autor de Comedias", de cuyo enlace fue uno de los testigos, Bernardo Blasco,

${ }^{62}$ En este mismo volumen, hemos podido recoger otros dos nombres, tal vez pertenecientes a caballeros de la Orden del Santo Sepulcro: Juan Medina "Caballero de Barrachina", y Melchor "Caballero de Juslibol". 
mancebo músico, habitante de Calatayud. Sabemos también que el 26.09.1703 fallece el organista de la iglesia mosén Agustín López de Santa Cara. Al siguienllece el organista de la iglesia, mosén Agustin Lopez de Santa Cara Al diguiente año moría, a los 17 años, el infante músico Roque Bueno, natural de Paniza.

De 1705 - fecha en que fallece el músico mosén Juan Gascón-, data la primera noticia de que disponemos a propósito de mosén Domingo Buisán [citado "Buissan" en la documentación], que aparece entonces únicamente como "músico" de la iglesia a raíz de actuar como testigo de un matrimonio como "músico» de la iglesia a re nuestra Señora de Loreto del convento de los celebrado en la capilla de Nuestra Señora de Loreto del convento de los agustinos descalzos de la ciudad. Diez años más tarde, esto es, en 1725 mosén Domingo Buisán ( ¿y Borruel?) aparece ya citado como maestro de capilla del Santo Sepulcro, con ocasión de celebrar un matrimonio en el que la pilla del Santo Sepulcro, con ocasion de celebra en la documentación su deceso, como "presbítero músico".

A partir del año 1718 hallamos en el Sepulcro noticias relativas a una familia en estrecho contacto con la música apellidada Betrián o Vitrián, la cual milia en estrecho contacto con la música apellida se casaron Jaime Betrián y Ribas (†Calatayud, 1749), de familia procedente de Mequinenza -entonces bas (+Calatayud, 1749), de familia procedente de Mú muchos años como obispado de Lérida-, y Melchora Rodríguez. El, actuó muchos años como campanero y manchador en la iglesia. Del matrimonio nació en 1719 Jaime campanero yetrián, que llegaría años más tarde a ocupar el magisterio de capiRaimundo Betrián, que llegaría años más tarde a ocupar el mació el 02.041721.

lla de la iglesia, y su hermano Francisco Antonio, que nació el 02.04 .1721 .

Entretanto, el 09.02.1719 se había casado el organista Miguel Buberos del Tubo (*Epila, 1682; +Calatayud, 03.12.1726) ${ }^{63}$, y fue testigo de su boda el músico Joseph de Campos. Al morir Buberos, dejó como ejecutor de su testamento al bajonista del Santo Sepulcro de Calatayud mosén Francisco Miravete (tCalatayud, 1743).

En 1720 era tiple mayor de la iglesia mosén Juan López; al siguiente año, actuaba como infante Benito Villanueva. En 1724 actuaba como corneta José Guriel. Y en 1729 consta que murió, a los 13 años, el infante de coro Matías Álvarez, natural de Villadoz, en la comunidad de Daroca.

En 1733, se cita al músico de ascendencia catalana (natural de Torroella de Montgrí), que desarrollara su actividad como bajonista largos años en el Santo Sepulcro bilbilitano, Mateo Armench y Alandes (tCalatayud, 1763) ${ }^{64}$. En 1734 moría a los 58 años de edad poco más o menos, el "músico y tenor" de

a3 Contrajo matrimonio con Agustina Minguijón y Nieves, "haviendo precedido las tres canonicas moniciones que $\mathrm{S}$ to Concilio de trento dispone, y no haviendo resultado impedimento alguno"; samoniciones que el S.to Concillo de tra ho del beneficiado de Epila, licenciado Francisco Buberos bemos tambièn que este or ${ }^{64}$ Su primer apellido también se cita como Armenche, Arminche o Armenech, y el segurdo con Lorenza López Luengo: Calangued. Este bajonista tuvo en Calatayud dos hijos de
Antonio Manuel Vicente ("1733), y Josefa Ignacia ("1734). la iglesia Joseph Campos Marzo, sacerdote natural de Lirón, en la comunidad de Teruel (fue enterrado a expensas de su cabildo, "con toda honorificiencia"). También en 1734 falleció mosén Juan Molina, natural de Alhama, de 54 años, capellán y ministro de la iglesia, muy probablemente músico también.

En 1743 murió ya mosén Joseph Giménez, organista. Para mediados de siglo, disponemos de un libro de cuentas que nos facilita nuevas informaciones $^{65}$. Gracias a dicho libro conocemos la plantilla completa de músicos que actuaron en esta colegial entre los años 1749 y 1759 . Veamos el listado correspondiente al año 1749, y el salario de cada uno de los músicos:

Ignacio Oñate, Maestro de Capilla y Tenor... 45£00s; Tomás Hernando, Organista... 70E00s; Juan Antonio Oñate, Contralto... 45E00s; Ildefonso Osê, Contralto... $40 £ 00$ s; Pascual Bendicho, por 5 meses de Contralto... 12f10s; Francisco Porcar, Tenor... 50E00s; mosén Sebastian Perales, Sochantre... 50E00s; Cristóbal Blancas, Sochantre... 40E00s; Manuel Silvestre, Bajonista... 50£00s; Mateo «el Catalán», Bajonista... 40E00s; Miguel Dobón, infante tiple... 12f00s; Salvador Dobón, infante tiple... 12f00s; Ramón Portero, infante tiple por 3 Meses... 3f00s; Jaime Betrián Campanero y Manchador... 16E00s.

Sobre el maestro de capilla ahí citado, Ignacio Oñate ${ }^{66}$, también Tenor, desconocemos hasta el momento en qué fecha habría accedido al magisterio de capilla de la colegial del Santo Sepulcro ${ }^{67}$, aunque muy probablemente debió

${ }^{65}$ Manval de Qventas / de la Igl $l^{a}$, de el S.to Sep ${ }^{\circ}$. desde 1749. Asta el de 1759. Un libro con tapas de pergamino. Cfr. «Data de Salarios de Ministros en 1749», p. 34.

${ }^{66}$ Fue bautizado en la desaparecida iglesia parroquial de San Miguel Arcángel de Calatayud el 30.01.1707; le confirmó en aquella parroquia, junto a dos de sus hermanas, el 27.07.1713, el Obispo de Tarazona, D. Blas Serrate. Musicalmente, fue en primer lugar infante tiple de la capilla musical de colegiata del Santo Sepulcro. En 1727 y 1732 , aparece citado docuemtnalmente como testigo de sen dos matrimonios.

${ }^{67}$ Ignacio (Francisco Joseph) Oñate y Moreno, pertenecía a una familia de la que salieron otros vaIgnacio (Francisco Joseph) Oñate y Moreno, pertenecía a una familia de la que salieron otros va-
rios músicos activos en la Colegiata del Santo Sepulcro a lo largo de todo el siglo XVIII. Los miembros de esta familia - que se extiende desde finales del siglo XVII hasta bien entrado ya el siglo XIXsiempre aparecen registrados en la parroquial bilbilitana de San Miguel Arcángel, donde todos su componentes fueron bautizados, confirmados, casados, etc. La saga familiar se iniciaría con el prolífico matrimonio celebrado entre Francisco de Oñate y Gracia de la Herrera, que tuvieron no menos de nueve hijos. De dichos nueve, el segundogénito, Juan Antonio Oñate (*Calatayud, bautizado 10.04.1676; confirmado el 27.08.1676), sería el padre del mencionado maestro de capilla Ignacio Oñate, nacido de su matrimonio con María Moreno. La pareja tendría al menos cinco hijos, de los que el músico hacía el número tres: Ana María Josefa ("1703; apadrinada por el músico del Sepulcro Joseph Campos); María Teresa (*1704); el que iba a ser maestro de capilla del Santo Sepulcro, Ignacio; Lucía Paterna ("1710), y Antonia Raimunda ("1716). Nuestro músico recibió el sacramento de la confirmación a los seis años de edad, junto a sus hermanas María Teresa y Lucía Paterna. Tenemos nueva noticia de él a raíz del fallecimiento de su madre, María Moreno, acaecido en 1738, con motivo de cuyo desenlace su padre desembols 6 "en gastos de entierro y misas, diez escudos". Quedaron entonces como ejecutores testamentarios de la finada, su viudo, Juan Antonio Oñate, y su único hijo, el maestro de capilla Ignacio Oñate, actuando como testigo su tío Francisco Oñate. 
hacerlo muchos años antes que el mencionado año de 1749. Desde el año hacerlo muchos años an en la documentación conservada, citándosele en una ocasión junto al racionero músico de la colegial del Santo Sepulcro Joseph de Campos. Murió en 1764.

Resulta por otro lado harto interesante comprobar una presencia familiar, casi gremial, de la familia Oñate entre los sirvientes de la iglesia colegial, casi gremial, de la familia pues, además del maestro de capilla y del contralto citados (Matías Oñate, Mallidaban también del mismo modo, al menos, un macero (Matías Oñate, Macero... 20£00s) ${ }^{69}$, un capillero (Manuel Oñate, Capillero... 10£00s) ${ }^{70}$, un bajonista (Manuel Oñate, muerto en 1764) y un "sirviente" de la iglesia sin especificar (Matías Oñate, muerto en 1769).

Otros miembros de la capilla musical citada en el año 1749, también habrían pertenecido a familias con larga tradición en sus relaciones laborales con la iglesia del Sepulcro, o bien, habrían estado emparentados entre sí, como parece indicar sus conocidos apellidos ${ }^{71}$ : los Betrián o Bitrián de que ya tratamos, así como los Dobón, Hernando, Perales ${ }^{72} \ldots$

68 Parece en este caso, que el «Juan Antonio Oñate» citado en 1749 como contralto de la capilla musical del Santo Sepulcro, pudiera ser el entonces ya anciano padre del maestro de capilla lgnacio Onate (aunque habriamos de tomar en consideración que para el año 1749 contania ya con 73 anos). Ora posibilidad, es que se tratara de otro Juan Antonio Oñate, asimismo pariente del maestro de capilla: se trataría de un primo hermano del tenor y maestro de capilla, de nombre completo Ramón juan Antonio ("11.08.1716), segundo hijo de Francisca Pérez y de Francisco Oñate - este último, a quien ya vimos como testigo a la muerte de María Moreno, era, a su vez, hermano del padre del maestro de capilla-.

${ }_{69}$ La documentación disponible cita hasta cinco miembros de la familia llamados «Matías Oñate», que pudieran corresponderse con el mencionado macero, sin que seamos capaces por el momento de que pudieran corresponderse
identificar unos con otros.

${ }_{70}$ En fechas factibles para coincidir con el mencionado, se encuentran cuatro componentes familares llamados «Manuel Oñate»: • Manuel Francisco Oñate (1): hermano de Juan Antonio, y por tanto, liares llamados «Manuel Oñale» $\bullet$ Mel Pascual Oñate (2): hijo de Joseph (+1743), nacido en 1708, y apadritío del maestro de capilla; $\bullet$ Manuel Pascual Oñate (2) (3): primogénito de María Paessa y Matías Oñanado por Matias Oñate; $\bullet$ Manuel Ramón Joseph e -hermano de Juan Antonio, y por tanto, tó date (4): hermano menor del anterior, bautizado en 1729 .

${ }_{71}$ Hemos visto a Miguel Dobón y Salvador Dobón, como infantes tiples del Santo Sepulcro en

${ }^{71}$ Hemos visto a Miguel Dobón y Salvador 1749. En la documentación de la parroquial de San Miguel Arcángel, la fartir matrimonio entre Joseph Oñate vez primera con los Dobón (o "Donbón (*1730; +1812), de cuyo enlace arrancaría una nutrida descen$(+1790)$ y Francisca (Lorenza)
dencia en la capital del Jalón.

72 la falia

${ }^{72}$ La familia Perales, debió estar relacionada desde el comienzo cérez. Casi tres cuartos de siglo más latayud: aparece en 1672, cuando se casaron Juan Perane ados y comulgados de la iglesia, -y en 1744 tarde, en 1749 (aparecia ya un tal Tomás Perales-), se cita un mosen Sebá el registro del año $1749 \mathrm{como}$ trabajo percibia 50 libras. En 1746, se citaba al músico que va como diácono; en 1748, era testigo de la «mosén Sebastián Perales, subdiácono", y en 1747 aparece ya como diáconos 1751 sigue percibiendo su saboda del bajonista de la capilla del Santo Sepulcro, Manuel Silvestre. En como sochantre, fecha en la que se paga también en la misma iglesia colegial "a Juan Baptista Pe-
Por otro lado, la diferenciación entre monaguillos e infantes tiples resulta evidente, al confirmarse por separado un pago a los "tres infantes de sacristía" (21£12s). Aquel mismo año, se registraron gastos extraordinarios relacionados con la música por diferentes conceptos, entre los que hallamos gastos por vestuario, por arreglar los libros de coro, o por imprimir los villancicos de Navidad:

"M.s en una Ropa de coro $\mathrm{p}^{\mathrm{a}}$ el nuebo Tiple... 1E8s". "M.s p.r componer un libro de coro al librero... 2fs". "M.s por inprimir los Billancicos de Nabidad al Ynpresor... 3E08s". "M.s al Maestro de Capilla Ygnacio Oñate p.r lo que alcanzo en la Quenta de los Ynfantes de coro p.r todo este año de 749... 2f06s $4^{473}$.

La impresión en en hojas volantes de los textos de los villancicos de Navidad que se iban a interpretar en la iglesia del Santo Sepulcro, costeada por el cabildo, se constata documentalmente entre los años 1749 y 1759. Por entonces también, era frecuente pagar determinados servicios musicales prestados (especialmente, cantar el Passio) por músicos de fuera de la capilla, en especie, ya fuera, sobre todo, con chocolate, o incluso con tabaco, pañuelos, o carne - cabritos o piezas de tocino-. La lista de gastos y de nombres de músicos se prolonga a lo largo de años sucesivos.

La afluencia de público a las solemnidades con música debía asimismo ser notoria, a juzgar por las medidas tomadas por el cabildo en 1751: se pagó entonces por poner una pantalla en el coro "Ios días de Maitines cantados"; suponemos, que podría tratarse de algo así como una verja especial o un reflector para facilitar que el público pudiera seguir bien lo que sucedía en el

rales, por 5 meses y 24 días de sorchantre". Muy poco después, mosén Sebatián debió ir a opositar Santiago de Compostela, pues consta lo que se pagó entonces al cantor que le suplió en el coro. En 1752 continúa mosén Sebastián como sochantre, y también Juan Perales, aunque este último sólo durante 8 meses y 6 días. Ese mismo año, mosén Sebastián debió volver a opositar, esta vez en Valladolid, por lo que se pago en especie (en chocolate -antes se había hecho con chocolate, pañuelos y tabaco-) al religioso de la comunidad de la Correa que le sustituyó en el coro. En 1753-1756, mosén Sebastián sigue cobrando su salario íntegro (de donde se infiere que no habria tenido éxito en sus anteriores oposiciones, y que, además, su salario no había sufrido modificación alguna al alza durante al menos siete años). En 1757, aparece entre los confesados y comulgados de la colegiata y, aunque desconocemos la causa -promoción a otra plaza en otra iglesia, fallecimiento...-ese mismo año dejó sin duda su puesto como sochantre en la colegial bilbilitana, pues cobró ya únicamente "por 4 meses". Otros datos sobre los músicos Perales de esta época: sin fecha, se anota que este mismo mosén Sebastiân pagó 6 libras que debía al canónigo de la colegial Francisco Joseph de la Cerda; en 1759, fallecido el organista de la colegiata mosén Manuel Liarte, visitó su testamento D. Juan Perales. Y todavía en 1803, se registra, como padrino de la confirmación del más tarde activo músico de la colegiata Mariano Santos, a un tal Francisco Perales.

${ }^{73}$ Manval de Qventas / de la Igla de el S.to Sep ${ }^{\circ}$. desde 1749. Asta el de 1759. Un libro con tapas de pergamino. Cfr. «Data de Oja Extraordinaria en 1749», pp. 30 y 31. 
coro - situado tras el altar-, al tiempo que evitara que los fieles -aproximándose demasiado al presbiterio- se agolparan frente al coro en su afán por disfrutar de las extraordinarias galas empleadas y poder escuchar mejor la música interpretada.

En 1758 fallece el tenor Ramón Artal, y al siguiente año el organista mosén Manuel Liarte ${ }^{74}$. En 1763 debía ejercer como director de la capilla de música el maestro Najer.

En suma, el Setecientos va a ser una centuria de cierto esplendor para la colegiata, en la que - ya al menos desde el siglo anterior- se puede apreciar a partir del examen de la documentación conservada cómo algunos músicos (y no sólo maestros de capilla) podían llegar a disponer de varios criados y criadas a su servicio. Este hecho, verdaderamente excepcional hasta donde se nos alcanza, parece apuntar a que esta colegiata, agraciada por la nobleza de los caballeros y por las distinciones y prestigio de su ascendencia e importancia histórica, social y eclesiástica, debía de proporcionar a su personal en plantilla una consideración social verdaderamente privilegiada para la época en comparación con otras iglesias, aún de características superiores. En todo caso, parece que la riqueza de la iglesia se reflejó en todas sus actividades, y entre ellas, la música cobró un papel especial: sus músicos, a pesar de estar englobados en el apartado de "sirvientes", gozaron de un estatus 10 suficientemente elevado como para poder permitirse ciertos lujos, y el cabildo realizó dispendios anuales en materia musical, que cubrían, desde el cuidado por la indumentaria de los miembros de su capilla, hasta su diversión y recreo en festejos públicos.

Indumentaria de los residentes: Era una de las preocupaciones destacadas del cabildo del Santo Sepulcro: en 1752, se compraba "una vara de estadal blanco, para poner en la vara que lleva el Sábado Santo el que Canta el "Lumen Christi»" se mejoró también el vestido de los infantes y demás cantores, de manera que se compraban zapatos regularmente, botines de paño, medias, encajes, batistillas y telas de bayeta negra y estameña, paño negro "de Codos" para sotanas, chupas, calzones, manteos y sobrepellices; se pagaba al sastre para que apañara "las ropas viejas de monaguillos", se reparaban las albas, y se almidonaba y pagapas vijus de ban las costuras. En 1756, el cabildo se encargaba de comprar "cordelle de tres colores para faldares a las ropas, bonetes a los chicos y dos varas de mitán para forros a la ropa negra", "siete palmos de tafetán para los delanteros de una ropa, tres palmos de mitán para forrar los bonetes de los tiples, y seis jornales a pinch y onza y media de seda".

${ }^{4}$ De este último, sabemos que había ejercido como organista de la Colegiata de Medinaceli (Soria) entre 1747 y 1754 . (Vid.: PALACIOS, José lgnacio: La música en las colegiatas de la provincia de Soria. Soria, Diputación Provincial, 1997, pp. 142-143.
Cuidado de los textos para las funciones propias de la iglesia: El cabildo del Santo Sepulcro, en una localidad no excesivamente grande y seguramente con pocos talleres editoriales disponibles, se encargaba de imprimir los textos de sus villancicos; tampoco reparaba en gastos a la hora de traer materiales de fuera de ciudad: en 1751, se imprimió "el Rezo del Sto. Sepulcro", trayendo los ejemplares desde Zaragozanos ade Antuerpia") "para cantar las epistolas, traídos de Madrid", a los que se mando poner "23 piezas de bronce plateado para guarnecer las cubiertas" (el librero Diego Altube, fue el encargado de guarnecerlos "de terciopelo y galón"); y también es normal leer en la documentación de la iglesia cómo se compran varias resmas de papel de marquilla (i.e., de tamaño intermedio entre el papel de marca y el de marca mayor).

Recreo de músicos y residentes: Como nota curiosa de la esplendidez y celo capitular hacia sus empleados, el cabildo procuraba también su diversión: en 1752, se mandó poner "un tablado frente a la ventana que tiene la iglesia en la Casa de la Plaza, para que viesen los toros los sirvientes".

Otros gastos: Ocasionados por el mantenimiento habitual de la iglesia, se realizaron también otros varios gastos que afectaban a la música: en 1753 se mandaron arreglar las manchas del órgano; en 1758 se registran gastos por encuadernación, y otros originados por componer el organillo, unas tablas para libros, componer y copiar parte de un libro de solfa, encuadernar el de versillos, etc.; ese mismo año se arreglaron "el Organo grande y el Chico" (la iglesia contaba, además de con el órgano mayor, con un pequeño órgano, seguramente portátil, como los que solian emplearse para llevar en las procesiones - muy probablemente se traque "orillo" antes cht

te del "organillo" antes citado-; en 1759 se venden un violín del tenor Artal (por
$3 £ 4 s$ ) y un bajón de la iglesia (por 11£4s). [...]

Ya más avanzado el siglo (hacia 1777), comprobamos la lista de los miembros que conformaban la capilla de música del Sepulcro gracias a los grafitos anotados en las tapas de un cantoral del archivo. [Del maestro de capilla ahí citado, Jaime Raimundo Betriän y Rodriguez ("Calatayud, 24.09.1719; †Id., 1779), ya dimos breve noticia anteriormente]:

Maestro de capilla, Jaime Vitrian; bajonista $1^{\circ}$, Francisco Oliac; bajonista $2^{\circ}$, Joseph Contreras; tenor, Joseph Cases; tenor, Manuel Guillermo; contralto, Joseph Labana; contralto, Simón Alegre; y los infantes: tiple, Lorenzo Montuenga; tiple, Joseph Romanillos; y tiple, Juan de Funes.

En 1782, constatamos la presencia de un órgano, seguramente portativo, propiedad de la Colegiata del Santo Sepulcro. Entonces, el cabildo de la Iglesia de San Pedro de los Francos - que estaba reparando su célebre órgano gó- 
tico— ${ }^{75}$, solicitó que el capítulo del Santo Sepulcro le dejara prestado su órgano mientras durase la reparación de su órgano mayor.

En 1783 sabemos del fallecimiento del maestro de capilla y organista mosén Juan Francesch. Precisamente, éste es el primer maestro del que se conservan actualmente composiciones en el fondo de música a papeles de la colegiata, concretamente, una única obra: el "Tracto de Todos los Santos con violines y trompas", «Timete Dominum», en Re Mayor ${ }^{76}$.

En 1787, según se anota en el libro que lleva la signatura "Ms. 4" del archivo, habiéndose cantado el Passio en la Colegiata del Santo Sepulcro, asistieron a la capilla:

El maestro de capilla, Miguel Palacín y Cabrero; el bajonista y $1^{\circ}$ músico, Francisco Oliac; el bajonista y $2^{\circ}$ músico, Josef Contreras; tenor y $3^{\circ}$ músico, Manuel Gómez; el contralto y $4^{\circ}$ músico, Simón Alegre; el contralto y $5^{\circ}$ músico, Antonio Lloro; y los infantes: Antonio Gómez, $1^{\circ}$ infante; Pedro Utrilla, $2^{\circ}$ infante; Joaquín Cosuenda, $3^{\circ}$ infante; y Pascual Cosuenda, $4^{\mathrm{o}}$ infante.

Respecto al maestro Miguel Palacin, éste constaba unos años antes -en 1776 - como maestro de capilla de la vecina Colegiata de Santa María de la misma ciudad. Se conservan de él abundantes composiciones, en su mayor parte de tipo litúrgico (secuencias, salmos, responsorios, graduales...), y sus autógrafos revelan una caligrafía esmerada y peculiar. No podemos precisar con exactitud las fechas en que habría ejercido el magisterio de capilla en el Sepulcro, si bien hallamos obras suyas sin datar muy posiblemente de finales del siglo XVIII, junto a otras datadas en 1805, 1811 y 1815. Sabemos, por otra parte, que alguna de sus composiciones sirvió como método de estudio o ejemplo de contrapunto para otros músicos de la capilla, como, por ejemplo, un tal Manuel Martín, que anota en sus papeles que "estudió" las obras de $\mathrm{Pa}$ lacín. Los repartos de sus composiciones son por otro lado bastante austeros,

${ }^{75}$ El afamado órgano de San Pedro de los Francos conserva un espléndido y afiligranado pie de estilo gótico flamígero en madera tallada del siglo XV. Fue arreglado en 1600 por el conocido maestro organero, "francés de nación", Guillaume de Lupe, que en 1601 reformaba por completo el órgano de la vecina Catedral de Tarazona, ciudad donde residía. Años más tarde, en 1700, este preciado órgano sería reparado por Francisco (José) Sesma, y en 1774 por Francisco Turull. Ese mismo año, durante las obras de reparación, se trajo un órgano portátil de la colegial de Santa María. En 1776 se arreglaban las puertas del órgano y el secreto; en 1777 se mudaba el registro de clarines del pie a la mano y se añadían 9 flautas, y en 1782 se acordó una nueva composición del órgano, durante la cual, como va dicho, se pidió prestado el órgano de la colegial del Santo Sepulcro. En 1783 remata el instrumento el maestro organero Jerónimo Turull, muy probablemente hijo de Francisco. Todavia en 1784 se refieren pagos a un fraile cartujo que compone pisas y contras.

Anotado en partichelas, con una caligrafia muy cuidada, para el siguiente reparto: $S, A, T, b$; vl 1,2 ; cor 1, 2; acompañamiento. fis. y suelen reducirse a violines y trompas -en algún caso aislado aparece el bajón-, con el preceptivo acompañamiento continuo, destinado por lo general al órgano. No obstante, sus obras debieron estar en uso en la iglesia hasta la paulatina desaparición de la capilla de música a lo largo del siglo $X X$, lo que llevó a que algunas de sus obras fueran re-orquestadas o se les añadiera alguna instrumentación (particularmente, flautas y clarinetes), como nos consta por un ejemplo "renovado" en el año 1903.

De la larga época en que posiblemente rigiera la capilla Palacín, podemos precisar, que, en 1792, murió el músico Francisco Oliac, o que, en 1798, murió el "subchantre que fue", y luego sacristán durante muchos años, Ambrosio Antequera.

Más vagas son ya algunas otras noticias de que disponemos: en algún momento indeterminado de los siglos XVIII ó XIX, habrían sido infantes de esta iglesia (según sus propias notas en el Libro de atril de signatura "Ms. $3^{\prime \prime}$, que data del siglo XVIII), los tiples Florencio B., Benito Lafuente, y Manuel Martín (seguramente el mismo que citábamos antes como estudiante de las obras de Palacín).

Tampoco podemos precisar por el momento la fecha concreta en que pudo haber sido maestro de capilla y organista el músico oscense - natural de Botaya-Miguel Antonio Osanz (*1762; +1825), como consta por unas Completas en Re Mayor conservadas en el archivo del Sepulcro de Calatayud ( $E$ CALs, 16/354), cuyo título dice así: "Completas por D. Miguel Antonio Osanz, Maestro de Capilla y organista de la Colegial del Santo Sepulcro Yerosolimitano (en aquel entonces) de la Ciudad de Calatayud"77.

Ya con seguridad en el siglo XIX, sabemos que el músico Manuel Gómez fallece en 1805, así como Miguel Nogueras dos años después. En 1809 muere un músico no-residente, el parroquiano Pedro Gil, "clarinero del regimiento". En 1811 es ya el músico contralto Simón Alegre - a quien veíamos como responsable de copia de diversos cantorales- quien fallece. En 1812, el capítulo de Santa María admitía por sochantre al padre Morera, hasta entonces ocupado en la iglesia del Sepulcro. En 1817 muere el músico Manuel Santos. En 1821, el sochantre mosén Florencio Ybarz; en 1822, el bajonista mosén Pedro Martín. Y antes de 1826, fecha en la que opositó a la organistía de la Catedral de Albarracín, siendo entonces "Organista de Calatayud", era organista en la

77 Esta obra conservada recoge en su reparto, entre la partitura manuscrita y las partichelas añadidas, la siguiente distribución: $\mathrm{S}, \mathrm{A}, \mathrm{T}, \mathrm{B} ; \mathrm{vl}$ 1, 2, vlne; fl, cl, bajón; cor 1, 2; acompañamiento. Sobre el maestro Osanz, activo largo tiempo en la Colegiata de San Pedro de Soria, pueden verse: PALACIOS José Ignacio: La música en las colegiatas..., Op.cit., pp. 190-197. SÁNCHEZ, Montserrat; y GONZALO, Jesús: Catálogo del Archivo Musical de la Concatedral de San Pedro Apóstol de Soria. Soria, Caja Salamanca y Soria, 1992 
capital del Jalón el músico Juan Mateo, natural de Teruel, quien suponemos pudiera haber sido organista de la colegial del Sepulcro, al estar dicho cargo en Santa María ocupado en aquellas fechas por Juan Angel Sánchez.

A mediados de siglo aparece en la colegial la interesante figura de Mariano Nemesio Santos Iranzu, normalmente conocido únicamente como " $\mathrm{Ma}$ riano Santos". Este músico, prolífico compositor, se había formado en Calatayud como infante de coro de la Colegiata de Santa María (1810-1813). En 1810 consta ya en las actas de Santa María "un Memorial de los Musicos del Sepulcro Santos y Perez, solicitando alguna gratificacion por haber aiudado a los Musicos de la Yglesia en la fiesta de Velilla; se combino en darles un peso duro a cada uno" (cabildo ordinario del 09.11.1810). En 1813 el capítulo de Santa María le aumentó la paga "en consideracion su habilidad". En 1817 se continúa citando en Santa María al ministril Santos, y al músico Pérez.

En la colegial del Santo Sepulcro, hemos podido ver numerosas referencias a Mariano Santos en calidad de copista de música, y más tarde, contralto de la capilla de música de dicha colegial del Sepulcro (así consta en 1826), para pasar años más tarde a ocupar el puesto de maestro de capilla en la mencionada iglesia (se le cita como tal en 1858, aunque probablemente lo fuera desde mucho tiempo atrás). Murió desempeñando su cargo en 1867, cuando consta documentalmente como "Profesor de Música".

Su labor en esta iglesia pasa por la de recopilador y copista de la música de los maestros más afamados bilbilitanos (Palacín, Sánchez, Rotellar...), así como de autores extranjeros: de su magisterio debe datar la adquisición de varios impresos con música de cámara, y otras obras instrumentales de autores como Haydn o Pleyel, y la copia de obras dramáticas conocidas, fundamentalmente oberturas, recitados y arias de autores italianos como Rossini, Pacini, Ricci, u otros. De modo semejante, consta en diversas partituras sus orquestaciones y arreglos de composiciones de autores como por ejemplo Ramón Carnicer, o las dedicatorias que le dedicaron otros músicos activos, como el organista de La Seo zaragozana Francisco Anel.

Por su parte, él mismo compuso un abundante repertorio para la capilla que regía, entre el que destaca, además de las obligadas piezas litúrgicas, un nutrido grupo de composiciones dramáticas en lengua romance (villancicos, oratorios, zarzuelas, etc.). Las fechas que aparecen anotadas en sus obras van desde el año 1826 hasta 1858, siendo especialmente abundantes las datadas entre 1834 y $1858^{78}$

${ }^{78}$ Las hay datadas en los años $1834,35,36,39,43,46,48,49,50,56,57$ y 1858.
De los años de magisterio de Mariano Santos, contamos con varios nombres de los integrantes de la capilla musical del Sepulcro (anotados en el Libro de atril de signatura "Ms. 2"). Así, mientras era maestro dicho Mariano Santos, actuaban como músicos Eusebio Royo, Joaquín Siguienza, Domingo Ramos, Cornelio Cornelini, y Santos Pedro, siendo tiples Joaquin Bargas y Nicolás Santos, y tiple segundo Manuel Aramburo.

En esta época, la desamortización de Mendizábal iba a hacerse sentir también en Calatayud: en 1838, sabemos del fundado temor ante los despidos, por parte del colectivo músico de la ciudad -preocupado por su situación económica y laboral-, aunque constatamos de nuevo el especial cuidado que tenía el capítulo del Santo Sepulcro por su capilla musical, cuando vemos que, en carta del maestro de capilla de la Colegiata de Santa María, Ángel Sánchez, seguramente a su abad superior, le pide información acerca de cuándo va a cobrar él y su capilla, ante las nuevas disposiciones gubernamentales; éstas, habían llevado a que "en Tarazona despidieron los sirvientes desde Agosto [...]; pero [...] ni en Borja, Corella, Zaragoza, y el Sepulcro, se ha hecho esto: $y$ en el último dicen que en tanto no tengan una orden terminante para no pagar, seguirán pagando".

Malos tiempos, que no debieron afectar de manera sustancial a la capilla musical del Santo Sepulcro, a juzgar por los materiales e informaciones recopilados.

Del tiempo de magisterio de Mariano Santos contamos por otra parte con alguna otra noticia aislada, particularmente referida a fallecimientos de músicos: así p. ej., el óbito en 1855 del sochantre Manuel Bosqued; en 1864, muere el músico Nicolás Santos; en 1877 muere "de calenturas tifoideas" Eusebio Royo y Pérez; y el siguiente año, "de un cólico crónico", Alejo Cabello y Torcal.

Ya hacia finales de siglo, aunque no podemos de momento precisar con exactitud cuándo, ejerció el magisterio de capilla del Santo Sepulcro de Calatayud Ildefonso Pardos (seguramente, Lezaún de segundo apellido). Parece el iniciador de una dinastía de músicos bilbilitanos del mismo apellido ${ }^{79}$, y él mismo consta en diferentes facetas de la actividad musical ${ }^{80}$. Fue además maestro en su capilla de un infante tiple que sería más tarde un celebrado compositor, Pascual Marquina. De este último, nos ha quedado alguna ano-

${ }^{79}$ Entre ellos, José María Pardos Lezaún, autor de un Responsorio de Navidad "Hodie nobis" en Re Mayor, e instrumentador de un "Ave María" del maestro Lázaro Gainza, e Ildefonso Pardos Arrúe, que, ya en el segundo tercio del siglo XX, actuara como maestro de capilla y organista de la Colegiata de Santa Maria de Calatayud.

Aparece en el archivo como compositor de una "Misa a dos voces" en Sol Mayor, arreglista (or-
Apara de Calatayud. questador) de un "Miserere" del maestro Mariano García (1886), y director de la ejecución en Calatayud de la "1" Misa Dominguera" del maestro Francisco Javier García "el Españoleto". 
tación autógrafa infantil, registrada en una "Misa en Fa Mayor" del maestro José Sobejano, así como en una "Misa de Difuntos en Mi bemol Mayor" de Casto Gimeno. Y del mismo músico bilbilitano ${ }^{81}$, se conserva en la vecina Colegiata de Santa María un manuscrito autógrafo de su "Himno a la Virgen de la Peña" en Do Mayor ${ }^{82}$.

Serafín Larroca Saura consta como nuevo maestro de capilla del Santo Sepulcro: iba a serlo en 1889 (poco antes, ese mismo año, aparecía como músico de Santa María, donde se le citaba como casado, y de 42 años) ${ }^{83}$ y hasta al menos, 1893. En este último año ${ }^{84}$ eran miembros de la capilla de música Miguel Lezaún, Enrique Comes, Jacinto García, José M. Pardos y Mariano Clemente. Al año siguiente poco más o menos, se debió redactar una interesante carta conservada en el archivo, gracias a la que podemos conocer varios nombres de músicos de la ciudad, así maestros de capilla como organistas. La epístola va firmada por un tal "M. L.", probablemente sacerdote por el tono que emplea, y está dirigida a "mosén Amado"; nos relata un problema de prerrogativas de las capillas musicales, a partir de la pretensión, entonces novedosa, de que las capillas de música de Santa María y del Santo Sepulcro asistieran alternativamente cada año a determinadas funciones en San Juan el Real, algunas de las cuales, como p. ej. las de San Juan y Santa Lucía, desde tiempo «inmemorial» correspondía únicamente acudir a la capilla musical del Santo Sepulcro. Ésta última por su parte, se negaba a perder su privilegio, y pretendía acudir a tal

81 Pascual Marquina Narro ("Calatayud, 16.05.1873; +Madrid, 13.06.1948). Hijo de Santiago Marquina, director a su vez de bandas civiles (entre ellas, la "Unión Bilbilitana"). Estudió armonía y composición en Barcelona con Martínez Sorolla, Bonet y Varela Silvari. Dirigió la banda municipal de música de Daroca -1890 - y luego la del batallón de zapadores de Llerena en Madrid -1901 - Autor de música militar, y principalmente para banda. Director de la discográfica "La voz de su amo". Fue también director de zarzuelas de éxito (fue maestro director $y$ concertador del Teatro de amo". Fue te Madrid -1913 - t, comolas de exito (fue maestro director y concertador del Teatro de la Zarzuela de Madrid -1913-), como El querer de una gitana, La Gioconda, Sangre y arena, La ultima copia, Sant Maria del Mar, Sol y caireles, Madrid en broma, La bandera legionaria o El tren de lujo. Compuso melodías como el pasodoble "España cañi", y se le conoció como el "rey del pasodoble".

${ }^{82}$ La pieza conservada en Santa María ( $E$ : CAL, 34/431), lleva letra de Joaquín San Nicolás Francia y su reparto es como sigue: $S(5 x), T(3 x), B(4 x)$; vl 1,2, vlc, cb; fl, cl, fag; org (2x).

${ }^{89}$ Matricula de la Parroquia Maior de Santa Maria de Calatayud en el año de 1889. Esta fecha se corresponde exactamente con la de la determinación del entonces obispo de Tarazona y Tudela ye mas tarde cardenal-arzobispo de Zara da. D. Juan Soldevila y Romero, de orgmizar a partir de sus nume re cardenal-arzobispo de Zaragoza, D. Juan Soldevila y Romero, de organizar, a partir de sus numerosas iglesias, cuatro grandes parroquias para la ciudad de Calatayud, todavia existentes: las conforma en torno a las principales iglesias parroquiales de San Juan el Real y de San Andrés, respectivamente. En tales grandes mayor asiduidad, y por tanto, donde se ha conservado el mayor número de materiales histórico-musicales de interés para nuestra investigación.

De entonces (año 1893) data un Convenio o capitulaciones de la capilla de música de la Colegiata del Santo Sepulcro. funcion solemne todos los años, como hasta entonces, sin tener que turnarse con la capilla de Santa María. Dice así la carta:

"De inmemorial y por lo tanto en derecho, despues de haber estado / de Curas Parrocos en la Igla. de S. Juan M.n Mariano Bellido, M.n Mariano Seta y M.n Ma / riano Martinez y de haber sido Organistas de dha. Iglesia de S. Juan los maestros de la Capilla de Sta. Maria, Juan Pablo Lopez, Mariano Na / varro, Roque Perales y otros, llegó el día de la traslación de M.n Mariano / Martinez quedando Cura economo M.n Francisco Sancho Beneficiado / de dicha la referida dando Cura economo M.n Francisco Sancho Beneficiado / de dicha la referida
Iglesia de S. Juan, el que á pretexto de que el Organista era $\mathrm{Ma}$ - / estro de la $\mathrm{Ca}$ Iglesia de S. Juan, el que á pretexto de que el Organista era Ma- / estro de la Ca-
pilla de Sta. María (despues que llebava 13 años de Orga / nista en dicha Iglesia (y para evitar dudas de á quién corresponden estas / cuarenta horas ó las otras, mes y medio (7 Junio 94) ó dos meses antes / de tomar posesion el $\mathrm{Sr}$ Cura $\mathrm{Pa}$ roco M.n J. A. Brabo, llamó a los encargados de dichas $\mathrm{Ca} / \mathrm{pill}$ musicas que lo heran Enrique Comes y Vicente Callastegui y les dijo / que en lo suscas que formaba turno de las funciones astiendo a ella / un Capill lo sucesivo se formaba tienda cada, metiendo en turno las funciones de S. Juan que de inmemo- / rial (y el mismo Sr. Vicario puede justificarlo) á asistido la Capilla del / Santo Sepulcro á la de S. Juan y Sta. Lucia (cuando se encontrava en dha. / Iglesia) dejando de hacerlo de las de meter en turno las 40 horas de Carnaval, q.e igualmente asiste / de antiguo la referida Capilla de Sta. María. / Los individuos de dicha Capilla musica del Sto Sepulcro no estubieron / conformes y lo dejaron hasta que tomara posesion els. Cura en propiedad, / llegó este dia y sin embargo de harle hos por escr. saber la arbitrílidad del $\mathrm{S}$ / Cura Econo dia econo que no á puesto remedio como asi lo prometio / Dichos / individuos de dicha la referida Capilla musica del Sto. Sepulcro / dezian que se respete la antiguedad como un derecho / y por lo tanto sin mas interrupcion asistan á la / Festividad de S. Juan, todos los años, sin interrupcion. / Menos por q.e se me resiste q.e una vez de ese modo no se respete lo antiguo siento llamar tu atencion pero no puedo / Ap.o amigo Amado: mis compañeros / querian dirigirse á ese Ilmo Sor en reclamado de / derecho q.e les asiste en el asunto á que hace referen- / cia la adjunta relacion, pero yo por mi parte me dirijo pongo los medios / pa qe no sjiga relacion, pejuague entre M.n Fran.co, M.n Pedro, Gallastegui / y el [?] pase mas adelante; de forma que si lo encuentras confor-/ me y en buena armonia deseo que llames á M.n Juan Ant.o Brabo / y le digas lo que hay aun cuando él debe conservar la relacion / de lo acahecido q.e se le entrego al tercer día de tomar posesion de su Paro- / quia. Si comprendes que nada puede conseguirse lo dejas / sin efecto, pero amigo repito q.e se me resiste despues de haber / asistido á dha. funcion desde que fui infante, $y$ tu lo habrás recordarás / de ello. / Por todo te pido mil perdones y Anticipadamente / da las gracias su afmó. amigo / M. L."

Gracias a esta carta, sabemos que el Enrique Comes que actuaba como miembro de la capilla musical del Sepulcro en 1893, había pasado ya al año siguiente - 1894 a ejercer el cargo de maestro de capilla en la misma iglesia.

De comienzos del siglo $\mathbf{X X}$ datan ya sendos presupuestos conservados, para el cambio y ampliación de las contras y reunión de los teclados del ór- 
gano de esta colegiata, así como para la construcción de un nuevo órgano ("todo Expresivo, siendo la fachada exterior con armonía al estilo de la Iglesia") que constaría de dos teclados y pedalier, ambos realizados por la fábrica de órganos y armoniums de Cayetano Estadella, sita en Gracia (Barcelona) casa que obtendría "Medalla de Oro en el certamen de Zaragoza de 1908.

Actualmente, junto al teclado, puede verse una placa de la casa organera "Inchaurbe Hnos.", que fue la que realizó el instrumento actual en el siglo $\mathrm{XIX}^{85}$. Este órgano, de factura romántica, consta de pedalier de una octava y doble teclado manual; en su remate, pueden apreciarse dos putti tañendo un antiguo bajón y una suerte de dulzaina o pequeña chirimía, respectivamente asimismo, se conservan los largos atriles utilizados tradicionalmente por los músicos de la capilla, los cuales eran colocados en la tribuna del órgano principal y del órgano falso (sólo presenta la fachada) enfrentado a él.

Por último, podemos todavía anotar la maestría en los años 30-40 del siglo XX de Luis García Bellés, que fuera mentor musical del joven infante Jacinto Alcoitia, cantor de la capilla jerosolimitana y su último Prior.

Hasta aquí, hemos tratado no sólo de música, sino, más bien, de "documentos para la historia de la música". Historia. Material de archivo. Documentación. Nombres y fechas de actuación de músicos del pasado y sus obras. Positivismo, en fin, en datos y nombres de un caso local, uno más, de lo que fue y pudo haber sido nuestra música en tiempos pretéritos. Pero, no hay que perder de vista, que el positivismo del dato, junto a la imprescindible aplicación de la Filología en el tratamiento de las fuentes, suponen una condición indispensable para la obtención de fiabilidad y, con ello, para una adecuada evolución y desarrollo de la historia.

Hemos intentado esbozar una ínfima aportación musicológica, a modo de ejemplo, de entre la - afortunadamente- enorme cantidad de casos que se podrían plantear. Tan sólo un caso más, para concienciarnos de cuánto desconocemos todavía acerca de nuestro pasado, de nuestro "patrimonio" heredado, y de todo lo que todavía queda por hacer. Una tarea fascinante, que nos aguarda, a cuantos hasta aquí estamos interesados por la Musicología histórica, y a muchos más.

85 El organero de Zaragoza «Inchaurbe», fue asimismo el constructor del órgano del convento del Sagrado Corazón, de Sarriá (Barcelona). 